\title{
Role of Trace Elements in Alzheimer's Disease
}

\author{
Sanjeev Kumar ${ }^{1}$, Reena Mittal'2, Shweta Chaudhary'1, Deep Chand Jain ${ }^{3}$ \\ ${ }^{1}$ Department of Physics, Central Medical Physics Research Laboratory, D.A.V. (P.G.) College, Muzaffar Nagar, India \\ ${ }^{2}$ Department of Mathematics, K.K. Jain College, Muzaffar Nagar, India \\ ${ }^{3}$ Department of Neurology, Safdarganj Hospital, New Delhi, India \\ Email: sanjeev1962kumar@yahoo.co.in, sanjeev1962kumar@rediffmail.com, reena math@rediffmail.com, \\ drdcjain@gmail.com
}

Received 21 June 2014; revised 24 July 2014; accepted 4 September 2014

Copyright (C) 2014 by authors and OALib.

This work is licensed under the Creative Commons Attribution International License (CC BY).

http://creativecommons.org/licenses/by/4.0/

(c) (i) Open Access

\section{Abstract}

Atomic absorption analysis involves measuring the absorption of light by vaporized ground state atoms and relating the absorption to concentration. The incident beam of light is attenuated by atomic vapour absorption according to Beer's Law. The estimation of trace elements shows a colorful presentation of different metals. It has been seen and found that the levels of zinc, calcium, magnesium, aluminum are lower in Alzheimer's disease samples in comparison to healthy controls. The elements such as copper, iron, potassium and sodium were found higher than controls. A statistical analysis has been applied and measured regression with correlation coefficients including multiple correlation coefficients between different trace elements like $\mathrm{Na}, \mathrm{K}, \mathrm{Ca}, \mathrm{Mg}, \mathrm{Zn}, \mathrm{Cu}$, Fe and $\mathrm{Al}$ in normal samples. A trend has been found in coefficient of correlation such as $r_{\text {Ca.Mg }}>$ $r_{\text {Na.K }}>r_{\text {Cu.Zn }}>r_{\text {Zn.Al }}>r_{\text {Cu.Fe }}>r_{\text {Cu.Al }}$ with positive correlation and $r_{\text {Fe.Al }}>r_{\text {Fe.Zn }}$ with negative correlation. Coefficient of partial correlation is also calculated and found that a trend has been set up between trace elements and given here as $r_{\mathrm{NaK.Mg}}>r_{\mathrm{ZnCu.Fe}}>r_{\mathrm{NaK} . \mathrm{Ca}}>r_{\mathrm{CuFe.Zn}}$ with positive correlation and $r_{\mathrm{ZnFe.Cu}}>r_{\mathrm{ZnFeAl}}>r_{\mathrm{MgNa} . \mathrm{K}}>r_{\mathrm{CaNa.K}}>r_{\mathrm{MgK} . \mathrm{Na}}>r_{\mathrm{CaK} . \mathrm{Na}}$ with negative correlation. Multiple correlation coefficient in normal healthy person has been estimated and found that a trend, which is given here as $\boldsymbol{R}_{\mathrm{Zn} . \mathrm{FeCu}}>\boldsymbol{R}_{\mathrm{Fe} . \mathrm{CuZn}}>\boldsymbol{R}_{\mathrm{Zn} . \mathrm{FeAl}}>\boldsymbol{R}_{\mathrm{K} . \mathrm{MgNa}}>\boldsymbol{R}_{\mathrm{Na} . \mathrm{MgK}}>\boldsymbol{R}_{\mathrm{Cu} . \mathrm{FeZn}}>$ $\boldsymbol{R}_{\mathrm{Na.KCa}}>\boldsymbol{R}_{\mathrm{K} . \mathrm{NaCa}}>\boldsymbol{R}_{\mathrm{Ca} . \mathrm{KNa}}>\boldsymbol{R}_{\mathrm{Mg} . \mathrm{NaK}}$. Multiple correlation coefficient in AD samples has been estimated and found that a trend, which is given here as $\boldsymbol{R}_{\mathrm{Fe} . \mathrm{CuZn}}>\boldsymbol{R}_{\mathrm{Zn} . \mathrm{FeCu}}>\boldsymbol{R}_{\mathrm{Cu} . \mathrm{FeZn}}>\boldsymbol{R}_{\mathrm{Na} . \mathrm{KCa}}>$ $\boldsymbol{R}_{\mathrm{K} . \mathrm{NaCa}}>\boldsymbol{R}_{\text {Ca.KNa }}>\boldsymbol{R}_{\mathrm{Na} . \mathrm{MgK}}>\boldsymbol{R}_{\mathrm{K} . \mathrm{MgNa}}>\boldsymbol{R}_{\mathrm{Zn.FeAl}}>\boldsymbol{R}_{\mathrm{Mg} . \mathrm{NaK}}$.

\section{Keywords}

Alzheimer's Disease, Trace Elements, Flame Atomic Absorption, Multiple and Partial Correlation

${ }^{*}$ Corresponding author. 


\title{
Coefficients and Regression Equations
}

\author{
Subject Areas: Clinical Trials, Public Health
}

\section{Introduction}

Dr. Alois Alzheimer, a German physician presented a case of 55-year-old woman in 1906 who was a patient of progressive dementia. A history of Alzheimer's disease has started with this case. Dementia has been recognized since early antiquity. It has been associated with old age [1]. Progressive mental deterioration in old age has been recognized and described nicely in the literature. Dr. Alzheimer specifically identified a collection of brain cell abnormalities as a disease. A patient of Dr. Alzheimer died after years of severe memory problems, confusion and difficulty in understanding the daily use of general questions. A brain autopsy of the dead body has been done and doctor noticed that a dense deposits surrounding the nerve cells (neuritic plaques). He observed twisted bands of fibers (neurofibillary tangles) in the nerve cells. Nowadays, this degenerative brain disorder bears Dr. Alzheimer's name. These plaques and tangles mean a definite diagnosis of Alzheimer's disease (AD). Many scientists discovered a link between cognitive decline and the number of plaques and tangles in the brain. The medical community then formally recognized Alzheimer's as a disease. It was not a part of aging.

The term Alzheimer's disease was coined by Emil Kraepelin. He studied psychiatric disorders. Dr. Kraepelin was so much impressed with Dr. Alzheimer's work that he appointed to work as a head of Department of Pathology at a Psychiatric Institute in Munich. It is called Max Planck Institute.

Reger, B. [2] has given new aspects regarding this disease. People are understanding that a grandparent, parent, elderly relatives, friends can no longer remember names or faces, recognize common objects or talk in coherent sentences of daily use. These persons may be suffering from Alzheimer's disease. This disease is a growing medical and social concern.

A degenerative disorder attacks brain and leads to dementia. The brains cognitive centers are very much affected. A memory loss, inability to understand situations or even question or statements are the features caused by this disorder. Due to the progression of this disease, social interactions diminish and the person loses the ability to care for him or herself. It has been noticed that before the discovery of Alzheimer's disease, scientist and non-science community have given their views on dementia. Whaley, N. S. [3] has given a statement that a dementia is a natural progression of age and senility, which was accepted as a part of aging.

Rebecca, C. et al. [4] have projected an overview of environmental risk factors in neurodegenerative disease. Alzheimer's disease is the prototypical degenerative disease affecting the central nervous system (CNS).This disease is a chronic progressive disease characterized by memory loss and deficits in one or more of the following cognitive domains. These are aphasia known as language disturbance, agnosia apraxia, or executive function. Such types of deficits must be severe enough to interface with daily work of life. There is a significant decline from an earlier level of function. Alzheimer's disease is a form of brain disease, can lead to confusion, memory loss, restlessness, problems with perception, speech trouble, trouble moving and fearing things, which were absent at that time. The patient may become too excited; refuse food and loose bowl or bladder control. This neurological perturbation generally starts in late middle life with slight deficits in memory and behavior. This disease occurs in both the sexes. The exact causative mechanism of the disease is unknown. It has been seen that there is a breakdown of cells in the brain. There is no treatment of the disease available and a good nutrition may slow down the progress of Alzheimer's disease.

Senile dementia is marked by the degeneration of some of the neurons. These neurons produce acetylcholine and communicate with the neocortex. The blockage of acetylcholine receptor interferes with memory formation in normal healthy people. The loss of acetylcholine-containing neurons underlies the memory deficit in Alzheimer's disease. There are two varieties found in Alzheimer's disease. These are simple deterioration and paranoid tendencies. Simple deterioration involves the gradual loss of various mental capacities such as loss of memory for recent event, progressing to disorientation, poor judgment, neglect of personal hygiene and loss of contact with reality. A paranoid tendency involves marked suspicion, often convinced others are engaged in various injurious plots. The disease develops differently for every individual. There are so many symptoms, which are common. Early symptoms are mistakenly thought to be age related concerns or manifestations of a mental stress. 
Alzheimer's disease develops for an unknown and variable amount of time before fully apparent. This disorder can progress undiagnosed for many years. Mental stimulation, exercise, and a balanced diet have been suggested to delay cognitive symptoms in healthy older people. There is no evidence supporting an effect. This disease cannot be cured and is degenerative. The victimized person relies on others for help and assistance. Harry, V. et al. [5] have given their views on this neurological disease as it is a progressive neurodegenerative disorder with cognitive, behavioral and functional abnormalities. Alzheimer's disease is increasingly common as individuals age and typically lasts a decade from onset to death.

Lindy, E. H. et al. [6] have studied behavioral changes in early Alzheimer's disease and given few lines in understanding the presentation and progression of the cognitive impairment associated with Alzheimer's disease. Non cognitive symptoms like depression, psychosis, violence, agitation and disturbances of diurnal rhythms are concomitant to the progression of Alzheimer's disease. Robins, P. V. et al. [7] have studied the impact of dementia on the family and found that these symptoms are a major cause of anxiety and concern for care givers. Anxiety for upcoming events, purposeless activity, verbal outbursts and disturbances of diurnal rhythms frequently occurred in early stage of patients of Alzheimer's disease. Folstein, M. et al. [8], Reisberg, B. et al. [9], and Teri, L. et al. [10] have also shown that the same types of behavioral disturbances are also found in severely impaired patients. Berrios, G. E. et al. [11], Cummings, J. L. [12] and Cummings, J. L. et al. [13] found that delusions are more common in patients with higher levels of cognitive function. Cummings, J. L. [12] and Cummings, J. L. et al. [13] have shown that hallucinations have been also correlated to more advanced cognitive impairment.

Khachaturain, Z. S. [14] put forward views on status of Alzheimer's disease research. Author has reported some debilitating disturbances of old age and the most frustrating include those lead to a partial or complete loss of cognitive functioning. Alzheimer's disease is one of the most persistent and devastating dementing disorder of old age, eventually leading to a complete loss of memory and ability to learn. This neurological problem presents enormous problems to the families of victims and raises complex social and economic issues for the public at the same time the disease offers unusual scientific challenges.

Alzheimer's disease is no longer regarded as a natural consequence of aging. It affects a substantial proportion of the aged. Although the exact number of people affected is not known because of the difficulties involved is accurate diagnosis. It is estimated and speculated that more than 20 crore people have this disease in its various stages throughout the world.

The number and proportion of elderly in the world are rapidly increasing and are already profound influences on the world's affected populations, social and political thinking and behavior. Biomedical research and its applied technologies have made it possible for an increasing number of people to survive until their seventies or eighties.

Among the many age related disabilities, those related to changes in central nervous system (CNS) or brain functioning have important implications for both public policy relating to health care services and national priorities for biomedical research .Failure in cognitive functioning is one of the principal indications for institutionalization of the elderly on long term care facilities.

The first finding concern a protein present in nerve cells involved in the formation of two types of brain lesions such as neuriticpalques and neurofibrillary tangles. These are hallmark of Alzheimer's disease. The significance of finding is that abnormal protein is unique to the brains of Alzheimer's disease patients. It is absent in normal brain. It is also found in very specific regions of the Alzheimer's brain that have significant cell loss.

The dimensions of the health problems posed by aged-related changes in the CNS are vast. Basic fundamental research into the neurobiology of aging as the route to resolving these problems has been demonstrably successful in advancing knowledge of the human brain and providing the first real insight into some of the more baffing neurological disorders. These advances come out because of a critical combination of talent and technology in neurosciences. It is possible to have a detailed and clear cut picture of what happens at the molecular level of a nerve as well as a clearer idea of how large clusters of nerve cells and systems operate in elaborating complexes human behavior.

Investigations have to determine why brain cells die in Alzheimer's disease? And whether or not such cell death can be averted by pharmacological means. There are several working hypothesis concerning the possible mechanism of cell death. One of the most active areas of study focuses on the chemistry of neurofibrillary tangles within nerve cells that are classic pathological markers of Alzheimer's disease. These filaments are com- 
posed of highly insoluble protein formed by unknown chemical reactions. These insoluble protein masses might form a physical blockage that interferes with axoplasmic transport mechanism. It leads to cell death.

A focus on biochemistry of $\beta$-pleated protein, cross linking reactions and the enzymology of such reactions may be done and new avenues certainly open to understand the mechanism of the disease.

Ronald, C. H. et al. [15] have studied urinary and focal incontinence in Alzheimer's disease. It has been reported that urinary incontinence is the inappropriate and involuntary passage of urine .Its exact prevalence is not simple to establish because it may occur in varying degrees and the patients may deny having the problem. It prevalence is difficult to determine in Alzheimer's. There are four type of urinary incontinence in the patients normally seen. These are stress incontinence and functional incontinence. Amaducci, L. et al. [16] have given detailed view on descriptive epidemiology and risk factors for Alzheimer's disease. They have reported that dementia is one of the most common mental health problems in the aged population. It is characterized by memory loss associated with impairment in abstract thinking and judgment, disturbances in higher cortical functions and personality change. The magnitude of dementia in the population can be expressed by epidemiological indices. These are prevalence and incidence. Hasegawa, K. [17] estimated the prevalence of dementia for people aged 65 and older was $4.5 \%$. Nielsen, J. [18] have reported that this prevalence vary up to $18.5 \%$. Jorn, A. F. et al. [19] have estimated the prevalence rates ranging from $0.72 \%$ to $38.63 \%$ in the age group 60 - 64 of one group and 90 - 95 years of other group of patients of Alzheimer's. The heterogeneity of risk factor for Alzheimer's disease is very useful in analysis to distinguish between sporadic? Familial and autosomal Alzheimer's disease cases.

This disease is no longer regarded as a natural consequence of aging. It affects a substantial proportion of the aged. Although the exact number of people affected is not exactly known because of the difficulties involved in accurate diagnosis. It is estimated and speculated that more than four millions Americans people have this disease in its various stages. Ronald, C. H. et al. [20] have decided some factors that aggravate the symptoms in Alzheimer's disease. A generalized deterioration in functional activities of daily living is expected in patients with Alzheimer's disease. Progressive decline and gradual loss of higher cortical cognitive functions commonly spear head the deterioration. It has been seen that in some patients the rate of declining function and disability may accelerate. The reversible causes must be sought out at the time of acceleration of the disease. These causes must be treated actively. The underlying Alzheimer's disease process is not the cause of this sudden physical or mental deterioration. A person's mental functions are controlled by the brain, which is made up of $10^{10}$ nerve cells called neurons. Brain functioning depends on the number of brain cells, their integrity, and the efficiency of the blood circulation. Neurons have no nutrition stores. They depend entirely on the circulation to provide them with required and adequate quantities of glucose, oxygen and different types of other nutrients. An efficient circulation removes from the brain any waste or toxic elements that have been formed by the brain cells through their metabolic activity. If the blood flow is ineffective, not only will the nerve cells be deprived but also different waste or toxic elements will accumulate in or around neurons. The nerve cells cannot function properly under these conditions. The patients mental impairment may worsen. Patient may become confused, lethargic, apathetic, drowsy, irritable, violent and aggressive. Alzheimer's have a reduced number of brain cells. Patients are vulnerable to many factors that may interfere with the functions of the remaining nerve cells. There are some factors responsible for a rapid deterioration such as sudden reduction in the number of neurons, sudden decrease in the blood supply to the brain, diminished quality of blood reaching the brain, altered sensory perceptions, drugs and other influences.

Ronald, C. H. [21] had supplied some information with clinical presentation point of view. Alzheimer's disease had supplied some information with clinical presentation point of view. Alzheimer's disease is a dementia characterized by an insidious onset and slow rate of deterioration. In addition to the memory impairment that interferes with the patient's routine activities. There is other evidence of cognitive deficits. We have two types of findings such as positive and negative. Positive findings are a) amnesia (memory deficits), b) evidence of cognitive impairment, including ammonia, agnosia, aphasia and apraxia, c) insidious onset. We have some negative findings such as a) no other disease responsible for mental impairment, b) no meditation responsible for mental impairment and c) no clouding of level of consciousness.

Alzheimer's disease is characteristically irreversible and slowly progressive. It is punctuated by sudden bouts of reversible deterioration caused by other different diseases or factors apart from this neurologically disturbances. Gauthier, S. et al. [22] have supplied some information for the future diagnosis and treatment of Alzheimer's disease. It must be realized that the drug may be administered to many thousands of individuals. Some 
patients never develop the disease. Several classes of agents must be considered for such type of trial. We must use first trial as vitamin $\mathrm{E}$ consumption. It has been seen that vitamin $\mathrm{E}$ or vitamin $\mathrm{C}$ may reduce the prevalence of Alzheimer's disease. Vitamin E may block lipid peroxidation. It may block the toxicity of amyloid $\beta$-protein in cell culture. The use of stereoidal and non-stereoidalanti inflammatory drugs may reduce the prevalence of Alzheimer's disease. The case of estrogen may reduce the neurological disorders. Wells, C. E. [23] had given some information regarding differential diagnosis of Alzheimer's dementia. The availability of scant medical literature dealing with Alzheimer's dementia suggests that two historical features are useful in the differential diagnosis. First case is that most recorded cases of depressive pseudo dementia in the elderly, which describes a relatively abrupt onset and a rapid progression of symptoms with the patients progressing to an appearance of profound dementia over a period of only two or three months. This was not the course of most diseases that causes dementia and certainly not the course of Alzheimer's disease also. Second case belongs to the physician; he must always consider a diagnosis of depression if there is a previous history of depressive illness. A previous depressive history does not preclude the development of dementia. If other features of the clinical picture are found at a variance with dementia. The possibility of primary depressive disorders should get special type of scrutiny.

Hachinski, V. C. [24] had studied differential diagnosis of Alzheimer's dementia. Multi infarct dementia was coined to emphasize that when vascular disease is responsible for mental decline due to small or large cerebral infarcts. This is in contradistinction to the still prevailing view that atherosclerosis of cerebral vessels causes critical narrowing, leading to chronic shortage of blood to the brain .A mental deterioration has started due to presence of the above problems.

Brain lesions are not additive. They are multiplicative in nature. A further insult has a greater global effect than the sum of individual lesions, particularly if they occur over a short period of time. It is also important to recognize and treat vascular factors in patients with Alzheimer's disease. The brains of Alzheimer's are more vulnerable and their vascular disease may determine their rate of deterioration.

Cummings, J. et al. [25] have given views for the dementia evaluation. Accuracy of the correct diagnosis of Alzheimer's disease and exclusion of other types of dementia is aided by a comprehensive diagnostic evaluation. The assessment of demented patients include: complete blood count, serum, electrolytes including calcium, glucose, creatine, liver function, free thyroid index and tsh (thyroid stimulating harmone), serum vitamin $\mathrm{B}_{12}$ and syphilis serology, sedimentation rate, serum folate, human immune deficiency virus, chest $\mathrm{x}$-ray, urine analysis for heavy metal toxicology.

Henderson, V. W. [26] and Rochon, P. A. et al. [27] have suggested that women are more affected by Alzheimer's disease than men. It has been seen and found in literature that the 1.5 to 3.0 times more women than men develop Alzheimer's disease. The estrogen deficiency and menopause are related to Alzheimer's disease. The incidence of this disease increases after menopause in women. Estrogen has been shown to protect neurons from oxidative stress induced cell death in vitro, to stimulate nerve growth factor activity, and to modulate neuro transmitter systems and glucose utilization. Estrogen may also change serum apolipoprotein $\mathrm{E}$ and slow deposition of senile plaques. Howard, L. F. et al. [28] have studied neurological disorders of increased prevalence in women special reference to migraine, multiple sclerosis and Alzheimer's disease and reported their findings on the aspect of disease. Psychiatric management of patients with Alzheimer's disease should incorporate compassionate counseling, social services and good supportive care. Constant sympathetic orientation, while maintaining a familiar environment and routine are helpful in the line of action to treat the patients. The patients with Alzheimer's disease continue to live at home is stressful for care givers. Alterations in the behavior and personality of the demented family member can be emotionally disturbed. It has been seen that the care for demented continue regularly without any break.

Cotman, C. V. et al. [29] have studied mechanism of neuronal cell death in Alzheimer's disease. They have supplied important information related to underlying mechanism of neuronal loss. The excitatory amino acid-L glutamate not only mediates the majority of excitatory signaling in the CNS but also identified as a potent neurotoxin. Studies with excitatory agonists and antagonists have identified excitotoxicity as a pathological process that contributes the neuronal loss in a wide spectrum of neurological disorders, including ischemia, anoxia, hypoglycemia, and epilepsy and head trauma.

Greitz, N. H. [30] studied various inflammatory processes and suggested that cytokines may also have a role in the pathology of Alzheimer's disease. Inflammation is a general marker of the tissue damage in any disease. It may be either secondary to tissue damage in Alzheimer's disease or a marker of immunological response. Pat- 
terson. C. et al. [31] and Rosendorff, C. et al. [32] have studied and found that cardiovascular risk factor such as hypocholestrolaemia, hypertension, diabetes and smoking are associated with a high risk of onset and course of Alzheimer's disease. Soffrizzi, V. et al. [33] studied and found that the component of a mediteranean diet, which includes fruit and vegetables, bread wheat and other cereals, olive oil, fish and red wine, may reduce the risk factor of Alzheimer's disease. Panza, F. et al. [34] have studied the effect of light to moderate use of alcohol, particularly red wine associated with lower risk of Alzheimer's disease. Stern, Y. [35] has studied cognitive reserve in Alzheimer's disease. He found that those people were engaged intellectual activities, such as reading playing board games, completing cross word puzzles, playing musical instruments or regular social interactions show a reduced risk of Alzheimer's disease. This is compatible with the cognitive reserve theory. This theory states that some life experiences result in more efficient neural functioning providing the individual a cognitive reserve that delays the onset of dementia manifestations. Shcherbatykh, I. et al. [36] and, Rondeau, V. et al. [37] have shown an increased risk of developing Alzheimer's disease with environmental factors such as intake of metals particularly aluminum.

Cataldo, J. K. et al. [38] have shown that the smoking is a significant risk for Alzheimer's disease.

Khachaturian, Z. S. et al. [39] have provided some views regarding Alzheimer's disease. This disease together with other forms of dementia represents a major challenge for health care systems with aging population. It is associated with neurodegenerative changes which compromise not only cognitive functioning but also lead to a decline in functional abilities and induce a spectrum of psychological or behavioral symptoms. Goldmacher, D. S. et al. [40] and Schimitt, F. A. et al. [41] have made efforts to undertake to investigate pathology of Alzheimer's disease and develop suitable strategies of treatment. These strategies focus on long term preservation of cognitive and functional abilities or slowing down disease progression along with reducing behavioral symptoms and maintaining the patients quality of life. There is no specific treatment leading to reversal or stopping of the progression, an amelioration of the disease symptoms, which may delay institutionalization as well as a reduction of care giver (Timardar) burden and costs are realistic treatment goals to day.

It has been reported in the literature that using vitamin $\mathrm{E}$ by the Alzheimer's disease person a significant improvement in the function of human system was seen. A range of antioxidants was also applying to the Alzheimer's to see the effect of the antioxidants to the patients. Interactions of metals like copper, zinc, iron and other metals are also studying these days to prevent the onset of this disease. The trace elements are needed for the normal brain function. A beta amyloid may be toxic due to the change in the trace elements. High blood cholesterol and blood pressure may also accelerate the onset of the disease. A high level of amino acid hemocysteine is associated with an increased risk of developing Alzheimer's. High blood pressure can damage blood vessels in the brain and reduce the brains oxygen supply. The resulting oxidative stress may accelerate the buildup of $\beta$-amyloid protein.

Minerals are important to our health. These are inorganic, chemical is elements not attached with carbon atom. Minerals and trace minerals can be differentiated easily. These trace minerals are called trace elements. If the cellular body requires less than $100 \mathrm{mg}$ of eleven minerals is labeled a trace element and if accepts more than this level is labeled a mineral.

Trace elements are required in quantities of few milligrams or micrograms per day. A study of relationships of minerals with human health is very necessary and important. A balance of the level for minerals in every organ, tissue and cell of the human body may lead to a good health.

Minerals comprise only a fraction of total body weight. These are crucial for many functions of the human body. These include transporting oxygen, normalizing the central nervous system (CNS) and simulating growth, maintenance and repair of tissues and bones [42].

Romeyn, M. [43] has given a statement that the regulation of trace elements balance in the body is essential to survival. Every cell is a living organism and we must try to maintain its internal environment. The mobility of trace elements across cell membranes, between the extra-cellular and intra-cellular fluid forms the basis for the body's most primary functions. The electrical activity may be initiated; heart beats, nerve cells signal, muscles may respond, blood vessels may tighten or relax. Water balance should be maintained.

Most of the trace elements found in the tissues and body fluids are also present in the blood. Some of the metallic elements have a specific metabolic function and the presence of these is not merely the result of contamination from our environment. The trace elements, which are biologically active produce their effects through enzyme systems. Metalloenzymes and metal protein complexes are two systems. The former has a fixed amount of specific metallic ion per molecule of protein addition of an agent, which binds the metal inactivates the en- 
zymes and the later is a larger group of proteins loosely bound to metal. The metals may substitute for each other with fluctuating degrees of affinity and can be taken out from the body by the process of dialysis. Some of these complexes may have enzymatic activity only. Rests of these are concerned with transportation process only. Herring, W. B. et al. [44] have shown that chelation affects the activity of enzymes. Khurshid, S.J. et al. [45] and Suhaila, R. et al. [46] have shown that the essential metals at trace levels play a role in the human body and can cause some diseases when present beyond the limit of normal concentration.

It has been seen that the trace elements occur in the tissue of animals, plants and micro-organisms in very low concentrations. The concentration of these elements change highly among many elements. Their concentrations are also different among various living organisms and their parts. These differences are seen in nutritionally essential elements and also in those elements, which are associated with no vital function.

The trace elements have divergent roles to play depending upon their chemical form or combination and their position in the body fluids and tissues. The functional forms of the trace elements and their characteristic concentrations ought to be maintained with narrow limits if the functional and structural integrity of the tissues is to be safeguard and the growth, health and fertility of the individual have to be unaffected. Continued ingestion of diets that are deficient, imbalanced, or excessively high in a particular trace element invariably induces changes in the functioning forms activities, or amount of these elements in the tissue or fluids, so that they fall below, or rise above the normal and permissible limits or ranges. Biochemical disturbances in these situations develop along with physiological functions, which are influenced and structural disorders may arise due to the change with elements. Kumar, S. [47] has reported in his Ph. D thesis that the degree and duration of the dietary deficiency or toxicity, age, sex and species are important factors associated with the trace elements.

It has been seen that food is the basic need of life of a living organism. Everybody eats food whether it is vegetarian or non-vegetarian. Scientists were very curious about the food they consumed. Food passes in the body and affects the body. Food is the substance taken into the body that will help to meet the body's need for energy. It helps in maintaining good health, health growth, growth and reproduction.

Proteins are important and vital to any living creature. These are the important constituents of cells and tissues of the human body. Proteins form the important component of muscles and other tissues and vital body fluids like blood, cerebrospinal fluid (CSF) and synovial fluid in human joints. The proteins in the form of enzymes and hormones are concerned with a wide range of vital metabolic mechanisms in the body. They supply the body building material and make good the loss which occurs due to wear and tear. Proteins as antibodies may help the body to defend against infections. Proteins are one of the most important nutrients required by the body has to be supplied through the diet we consume. The dietary proteins are broken down into amino acids and absorbed and are used by the body for various functions like tissues building, replacement of proteins depleted, etc. Amino acids are used for providing energy to the body.

Fat is an important component of our diet. It serves a number of functions in the body. Fat is a concentrated source of energy and it supplies, per unit weight more than twice of energy furnished by either proteins or carbohydrates. Fat also imparts palatability to a diet and retards stomach emptying time. Fat in the diet can be of two categories, the visible and invisible. The visible fats are those derived from animal fats like butter, ghee which are solid fats and those derived from vegetable fats like groundnut, mustard, coconut, sunflower oil, till, which are liquid fats. Hydrogenated vegetable oil known as Vanaspati is a solid fat. These fats are triglyceride of fatty acids, both saturated and unsaturated. Animal fats like ghee and butter contain Vitamin A and D. These vitamins are not present in vegetable oils.

Some amount of fat is present in other foods like cereals, pulses, oil seeds, milk, egg, meat, etc. This type of fat contributes to the total fat and essential fatty acids content of diet depending upon the foodstuff present in the diet. Nuts, oilseeds, soya bean, avocado, pear and animal foods have a higher amount of invisible fat.

Minerals and trace elements are circulating in the human body. Some of these elements form part of body structural component and some others act as catalytic agents in different body reactions. Bones and skeleton are made up of calcium, magnesium and phosphorus and iron, which is a component of blood. Minerals like zinc, molybdenum, copper, manganese and magnesium are either a structural part or activate a large number of enzyme systems. Iodine is a part of hormone, thyroxin. Sodium, potassium are important elements present in fluids within the outside the cells and along with ions like chloride, bicarbonate and carbonate keep water and acid base balance.

Every individual absorbs minerals in a slightly different way, called biochemical individuality. Those nutrients that have not been transferred through the intestinal mucosal cell to enter the circulation have no meaning 
regarding the study of the elements. The variety of nutrients from organism's environment that have been made available by absorption must be transported through the circulatory system to the aqueous microenvironment of the cells. They may serve the purpose of participation in different metabolic processes in the cells on which the life of the total organism depends.

The absorption of minerals is dependent on many different factors related to the mechanism of human body. Mary, R.L.A. et al. [48] have reported that the addition of vitamins and minerals to food can be effective public health intervention to correct inadequate intake of nutrients in both the general society.

\section{Different Types of Trace Elements Circulating in Human System}

There are ninety two elements found in nature. We have some additional twenty two elements also. It has been reported in the literature that there are hundreds of isotopes of the elements exist. We may say the any one of which may play an undiscovered role in human health.

Alaxander, G. S. [49] reported that through geophysical forces, mixing of the earth's crust with water may provide virtually every mineral for our body, which requires maintaining health. The water is compatable with more substances that any known solvent. It is an ideal medium for transporting nutrients in the cells for the chemical reactions of cellular metabolism to take place. Human body contains lot of element out of 25 are divided into mainly three categories such as major, minor components and trace elements.

Pike, R. L. et al. [50] have given a statement that the major components, which make up 96\% of human body are composed of oxygen, nitrogen, carbon and hydrogen. Major elements found in the biological molecules such as proteins, nucleic acids, fats and carbohydrates and are capable to make-up the body. Hydrogen ions are very important for our cells to make ATP or energy. Water is also a medium for all the chemical reactions taken place in the human body. Water is a mixture of oxygen and hydrogen atoms.

Minor components make up $4 \%$ of our body. They may include calcium, phosphorus, potassium, sulfur, sodium, chlorine and magnesium. Some of these are necessary for chemical processes to run correctly. Our muscles need calcium in order for them to twitch properly. Enough calcium is required to our body.

Trace elements make up $0.1 \%$ of our body. They include copper, zinc, selenium, molybdenum, fluorine, iodine, manganese, cobalt, iron, lithium, strontium, aluminum, silicon, lead, vanadium, arsenic and bromine. These elements are essential for our body to function properly.

Zumkley, H. [51] stated that clinical experimental and epidemiological studies indicate that a large number of trace elements may be involved in the etiology of different human body disorders. Both increased levels of any trace element or reverse of this can influence the development of disease.

\section{Trace Elemental Effects on Human Health}

A very high concentration of the trace elements may prove toxic. Depletion in the concentration of essential trace elements may lead to create so many different metabolic instabilities due to dysfunction of enzyme. Different types of metabolic changes in human body are accompanied by changes made in the concentration of one or more trace elements in some body fluids, such as blood serum or plasma.

The trace elemental analysis from human hair, nails, and body fluids such as plasma, serum and cerebrospinal fluid has been stated in the literature as the best predicator.

\subsection{Trace Elemental Role in Human Body}

We are giving the description of some of the important trace elements here as follows.

\subsubsection{Copper}

The presence of copper in animals and plants is very necessary. Copper is most abundant trace element in human beings. This element is carried mostly in the bloodstream on a plasma protein. We may call it is ceruloplasmin. This element is firstly absorbed in the gut and transported to the liver bound to albumin. It is found in a variety of enzymes, including the copper centre of cytochrome $\mathrm{C}$ oxidase.

Human body needs copper for normal growth and health. It is said that copper is required to help body use iron. This element is very important for nerve function, bone growth and to help body use sugar and it is a component of a cofactor for different enzymes, approximately. Fifty enzymes are required copper to function prop- 
erly. Davis, I. J. J. [52] has given a statement that a young person requires one hundred to one hundred fifty milligram of copper daily. Copper in higher concentration is found in liver, hair, muscle and lung.

\subsubsection{Zinc}

Zinc (Zn) is a necessary trace metal of suitable importance in the dietary management of many human body complex disorders. A young person has $3 \mathrm{gm}$ of zinc. This trace element is found in all our cells. This element is essential for all forms of life. Many proteins contain structures called zinc fingers may help to regulate genes. The distribution of zinc in human tissues is well documented in the literature. Liver, kidney, bone, retina, prostate and muscle appear to be very rich in zinc. Burns, R.R. et al. [53] have studied and found that most of the red cells zinc is tightly bound to enzyme carbonic anhydrase. It is exchangeable with plasma zinc. Whole of plasma zinc is found with proteins. Sixty percent zinc is bound to albumin and thirty percent has binding with alpha 2 macroglobulin and the remainder with low molecular weight proteins including amino acids.

Prasad, A. S. et al. [54] have shown that zinc is bound to amino acids and serum proteins. Histidine, glutamine, threonine, cystine and lysine showed the most markable effects. The amino-acid-bound fraction of zinc may have an important role in biological transport of zinc. The stable zinc content is higher in albumin fraction. Similar concentrations of zinc were found in the $\alpha, \beta$ and $\gamma$-globulins. These are fraction of immunoglobulin G.

Kelin, D. et al. [55] have shown the first demonstration of a specific biological function critically dependent on the presence of zinc. They have also shown that carbonic anhydrase contains zinc and it is essential to the mechanism of action.

Riordan, J. F. et al. [56] have reported in the literature that there are more than seventy zinc metalloenzymes. Zinc metalloenzymes exhibit diversity both of catalytic function and of the role played by the metal atom.

It is evident that zinc in small quantities is present in various cell membranes. Most of the membrane-bound zinc is linked to a distinct macromolecule constituent lipoprotein fraction. Chavapil, M. et al. [57] have shown that the effect of zinc and other metals on aggregation of platelets and release of $\mathrm{H}^{3}$ serotonin activated either by collagen or epinephrine.

Prasad, A. S. et al. [58] have shown that a syndrome of iron deficiency anaemia, hepatosplenomegaly and dwarfism has been found to be associated with malfunctioning of zinc metabolism. Walravens, P. A. et al. [59] have studied and found that the orthopedic and CNS have relatively slow zinc uptake. This element remains tightly attached for a lengthy span of time. The deficiency of zinc leads to growth retardation or failure, lesions of the skin and its appendages, and impaired reproductive development and function. Psychological disturbances are reported in individuals suffering from acrodermatitis en-teropathic. Henkin, R.I. et al. [60] have studied zinc induced deficiencies in human beings and these are associated with neurological symptoms such as depression, poor concentration, nervousness and moodiness. Dresti, I.E. [61] has studied the hippocampus, which is rich in zinc. Zinc deficiency is associated with learning and memory defects similar to behaviour syndromes resulting from destruction of the hippocampus. Acute oral zinc toxicity has been reported to produce drowsiness and somnolence.

\subsubsection{Iron}

Fairbanks, V. E. F. et al. [62] have reported that the therapeutic indications for iron during the Roman era included alopecia, acne, dermatitis, wounds, hemorrhoids, gout, pulmonary diseases, diarrhoea, vomiting, weakness, edema, fever and cystitis . McCance, et al. [63] have reported that once the iron was absorbed by the human body, its excretion was very minimal and was not controlled either by gastrointestinal tract or by the kidneys. The plasma iron was in equilibrium with tissue iron. The level of plasma iron influenced the rate of iron absorption. The intestine regulates the rate of iron absorption.

Granick, S. [64] adopted and extended the hypothesis of ferritin as the mucosal regulator of iron absorption. This hypothesis was used and named as mucosal block theory. Moore, C. V. et al. [65] have shown that the plasma iron as the major form of transport iron. Flavoprotein enzymes of iron were discovered by Mahler, H. R. et al. [66] and Richert, D. A. et al. [67]. Fisher, H.et al. [68] have synthesized four ferroprotoporphyrin (heme) moieties.

Ingram, D. J. E. et al. [69] have extablished a three-dimensional picture of molecule with its four attached hemes. They have studied the nature of the bond between iron and globin. Now iron is stabilized in the ferrous state completely, which allows it to be reversibly bonded to oxygen. Due to this mechanism, hemoglobin works as an oxygen carrier. 
The iron in human serum was studied by Holmberg, G. C. et al. [70] Schade, et al. [71] have shown that the trace element iron may be bounded completely to transferrin.

Lipschitz, D. A. et al. [72] and Simes, M. A. et al. [73] have established a correlation between serum ferritin, concentration and storage iron.

\subsubsection{Magnesium}

Aikawa, J. K. [74] [75] showed in the studies related to magnesium and found that magnesium is associated with so many different biological processes.

Magnesium is present in a small concentration in all cells and it is necessary for cellular metabolism. This trace element is also present in bone along with calcium. It shares so many properties of calcium so far as absorption and metabolism and tissue distribution are concerned. Widdowson, E. M. et al. [76] have studied the magnesium content in human body and found a range of magnesium, which stated from 22.7 to $35.0 \mathrm{meq} / \mathrm{kg}$ weight of tissues. Magnesium reaches us in many forms. These are magnesium amino acid chelate, magnesium carbonate, magnesium oxide, magnesium oxide dolomite and magnesium sulfate. Seventy percent of human body magnesium resides in bones and teeth. This element is essential to the functioning of human body because it transmits nerve impulses, causes contraction of muscles and integral to healthy development of bones and teeth. Waterlow, J. C. [77], Clasen, H. G. [78] and AL-Ghamadi, S. M. et al. [79] have shown that the human body contains about $760 \mathrm{mg}$ of magnesium at the time of birth. It goes up to $5 \mathrm{gm}$ at the age of $4-5$ months and it reaches up to $25 \mathrm{~g}$ when a body attains an age of adult. About $30 \%$ to $40 \%$ magnesium is found in muscles and soft tissues. One percent is found in extracellular fluid, and the remainder is in skeleton. If we are going to consider the particular importance with respect to the pathological effects of magnesium depletion. We have to take into account the role of this element in regulating potassium fluxes and its involvement in the metabolism of calcium. Wester, P. [80] has shown that about $1 \%$ of magnesium is found in the extracellular fluid, inside cells, magnesium may be bound to phospholipids. It is very important to note that increasing dietary protein intake may increase magnesium requirements because high protein intake may decline magnesium retention .It is advisable that to completely understand magnesium function, it is very important to explore magnesium's relationship with calcium and potassium. Magnesium and potassium also have a close relationship. Magnesium is required for the function of sodium and potassium pump. If a magnesium deficiency occurs, then pumping of sodium out of the cell and pumping potassium into the cell may be impaired. Krasner, B. [81], Furukawa, Y. et al. [82], Stark, G. et al. [83] and Haigney, M. C. P. et al. [84] have studied and shown an effect of the level of magnesium regarding heart attack.

Alcoholism, renal disease, diabetes mellitus may all cause a deficiency of magnesium. Nausea, vomiting, anorexia, muscle weakness, muscle weakness, muscle spasms and tremors are the few symptoms and signs related to deficiency of magnesium.

Magnesium has an effect on CNS. It is used for a better sleep. This element may be used to calm irritated and over excited nerves. This is useful with epileptic attacks, convulsions in pregnant women and shakes with tremors in alocholism. If the level of magnesium is very low, the nerves lose control over muscle activity, respiration and mental processes. Nervous fatigue, ties and twitches, tremors, irritability, hypersensitivity, muscle spasms, restlessness, anxiety, confusion, disorientation and irregular heartbeat all respond to higher levels of magnesium.

\subsubsection{Calcium}

We know that $99 \%$ of calcium is found in the bones and teeth of a human body. Rest of the element resides in the soft tissues and blood of the body. Calcium is most important element of the body and human body structure is made up calcium and other minerals. We shall lie on the ground without calcium and not able to stand.

Ireland, P. et al. [85]. Heaney, R. P. et al. [86], Wilkinson, R. et al. [87] and Marshall, D. H. et al. [88] have studied the ingested calcium mixes with digestive juice calcium in the proximal small intestine from where it is absorbed by a mechanism. This process has an active saturable component and diffusion component .Calcium is absorbed by active transport during the low calcium intake mainly. This active transport is called trans cellular transport. High intake of calcium leads to increasing proportion of calcium, which may be absorbed by paracellular diffusion. The unabsorbed component appears in the faeces together with the unabsorbed component of digestive juice calcium. This is called as endogeneousfaecal calcium. The faeces contain unabsorbed dietary calcium and unreabsorbed digestive juice calcium. Urinary and endogenous faecal calcium are not the only 
forms of calcium for excretion. The calcium looses from skin, hair, nails must taken into account. The deficiency of calcium causes osteoporosis. Morris, H. et al. [89], Ebeling, P.R. et al. [90], Need, A. G. et al. [91] have shown that the calcium absorption decreases with the increase of age in both males and females.

Nordin, B. E. C. et al. [92] shown that the calcium content of human milk is $36 \mathrm{mg}$ per $100 \mathrm{ml}$. A lactating lady may produce $750 \mathrm{ml}$ of milk daily. It has been reported that $280 \mathrm{mg}$ of calcium can be fed to a new born child. Kent, G.N. et al. [93] and Lopez, J. M. et al. [94] have shown that the bone is lost during lactation and restored after weaning. Chan. G. M. et al. [95] have shown that the loss of calcium may be prevented by the supplementation of calcium. Calcium deficiency is very serious. Researchers have shown a low bone density. Due to low density, the fracture rate is very high in developing countries. The intake of calcium is also low. Rickets has not been reported in developing countries.

\subsubsection{Sodium}

Sodium was isolated in the year 1807 by passing an electric current through molten sodium hydroxide. The sodium quickly oxidizes in air and is reactive. The free metal is used for chemical synthesis, analysis and heat transfer applications. Sodium ion is soluble in water. Most of the sodium in the human body is found in blood and lymph fluid. Aldosterone hormone controlled partly the levels of sodium in human system. Adrenal glands are responsible for the hormone. The level of aldosterone in human body tells about the kidneys when to hold the sodium element in the body instead of passing it in urine. Small amounts of sodium may last through the skin during the process of sweating. The ability of the kidney to both conserve sodium in response to sodium deprivation and to excrete sodium in response to sodium loading are impaired with the aging factor. Blood pressure in the body has to be maintained at the prescribed and standard rates. If the standards of the pressure are failed, the system leads to serious damage of the blood vessels and results might be lethal.

\subsubsection{Potassium}

This element is very important for the proper function of all cells, tissues and organs in the human system. This is an electrolyte able to conduct electricity in the body, along with sodium, chloride, calcium and magnesium. It is very crucial element to proper heart function and plays an important role in skeletal and smooth muscle contraction, making it very useful for normal digestive and muscular function. This element acts as a conductor for energy impulses throughout the body. It triggers chemical reactions in the body.

Potassium ion diffusion is a key mechanism in nerve transmission, and potassium depletion in human. There are some neurological dysfunctions such as epilepsy, headache, migraine, muscular dystrophy and Alzheimer's disease developed by the fluctuations in levels of potassium in the blood.

\subsubsection{Hyperkalemia}

If we found the levels of potassium in the blood higher than normal value then a disease may occur, which is called hyperkalemia. This may be related to an increase in total body potassium or the excess release of potassium from the cells into the blood stream. Kidneys remove excees potassium from the body. It has been found in most of the cases that hyperkalemia is caused by disorders which reduce the ability to get rid of potassium. These disorders are such as acute kidney failure, chronic kidney failure, glomerulonephritis, obstructive uropathy and rejection of a kidney transplant.

\subsubsection{Hypokalemia}

Hypokalemia means serum or plasma levels of potassium below the normal value. There are two causes for hypokalemia defined here, one is related to overall depletion in body's potassium and the next is related to excessive uptake of potassium by the muscle from the surrounding fluids. It is well reported in the literature that need have potassium is to control muscle action. Hypokalemia can cause the heart to stop breathing.

Mild hypokalemia does not show any symptom understandable position is missing. If a person has moderate hypokalemia which is very important to diagnose easily by the help of some understandable symptoms such as confusion, disorientation, weakness and discomfort of muscles, discomfort in the legs. Severe hypokalemia may produce extreme weakness of the body, paralysis. Different types of paralysis such as flaccid, limpness, lung muscles are common. This type of hypokalemia may cause abnormal heart beat. Abnormal heart beat is dangerous for our heart and it is the sign of cardiac arrest. Hypokalemia does not show any symptom in healthy subjects because of the rich percentage of potassium is found in healthy persons. 


\subsection{Trace Elemental Role in Relation to Immunity}

Nutrition and health both are linked each other but the importance of trace elements on immune system is also a field of research, which was established in the last two decades. It is a field of understanding of adequate trace elements supplementation may be a good path to design a better nutrition, which protects human beings against infections.

Cell biology and molecular genetics are the branches of science have been facilitated main efforts to determine specific cellular and molecular functions of trace elements in maturation, activation and functions of host defense mechanisms.

Immune cells require a proper supply of trace metals to express and preserve the structure and function metalloproteins. These cells may also participate in energy production. Trace element levels can affect the immune function not only in a direct process but also by modulating plasma levels of hormones which are used to regulate the development and function of host deference cells. The trace elements may influence some mechanisms of non specific immunity by modulating inflammatory cell function.

It has been seen that the effect of mineral deficiency on acquired immune system can be demonstrated by examining the response of lymphocytes to $\mathrm{T}$ cells mitogens. The levels of trace elements may also affects the synthesis and secretion of cytokines and chemokines which modulate the activities of immune and other cells.

A good application of micronutrient which is also called as trace elements interventions is probably related to vaccine response in older stage in human beings. Mortality associated with influenza is more likely to appear in this population.

A significant physiological role of many trace elements in the development, maturation, and sustenance of the morphologic integrity and function of the lymphoid organs concerned with immunity has been well established.

The immune system plays a key role in the body's ability to fight against infections and reduce the risk of developing tumors autoimmune and degenerative disease. Nutritional deficiencies and excesses influence different components of the immune system.

\section{Review of the Literature}

Katz, M. [96] and Suskind, R. M. [97] have studied the influence of nutrition upon host immune compertence. Correlations of protein and energy nutriture and their role in immuno responsiveness have been studied byBongiorni, I. B. et al. [98] and Malave, I. et al. [99]. Many trace elements are critical for mammalian survival and reproduction. High consumption of highly refined and heavily processed food items reflect that the trace element content may be reduced significantly. Gershwin, M. et al. [100] have shown that the value of level of zinc may affect the phagocytic cell function the complement system and mast cell mediator release which can be seen at the efferent arm of immune response.

Rigas, et al. [101] have reported that an additional process due to which copper acts in altering immune response may involve an interaction at the level of the plasma membrane.

Calcium ion are involved intimately is so many aspects of lymphocyte activation such as blast transformation in response to mitogens. Calcium is known to complete in a number of biological systems.

\section{Aluminum}

Aluminum is the third most common element on the surface of the earth. It is most abundant. It is not known to participate in any natural metabolic processes. Underwood, E. J. [102] has reported that aluminum as such is not thought to be an essential component of the diet. Aluminum-containing compounds have been considered to be nonhazardous to health. There is a relatively little in the way of toxicological investigation of the element.

Over the past four decades, data have accumulated suggesting that aluminum plays a role in the pathogenesis of neurofibrillary tangle formation. Since the neurofibrillary tangles serves one of the principle histologic features of Alzheimer's disease. Daniel, P. P. [103] shown that the presence of aluminum in certain population of neurons serves as pathogenetic. It may be an etiological factor in the disease.

Ehmann, W. D. et al. [104] have studied brain trace elements in Alzheimer's disease using neutron activation analysis to determine the concentration of sixteen elements in selected brain regions and separated gray and white matter specimens from histologically verified Alzheimer's disease and age matched controls. They have shown that significantly different (less than 0.05 of probability p, mean concentration of $\mathrm{Br}, \mathrm{Cl}, \mathrm{Cs}, \mathrm{Hg}, \mathrm{Na}, \mathrm{N}, \mathrm{P}$ 
and $\mathrm{Rb}$ were observed in Alzheimer's bulk brain samples compared with normals. There was no difference in levels of Ag, Co, Cr, Fe, K, Sb, Se, and Se compared to Alzheimer's controls.

Cornett, C. R. et al. [105] have studied imbalances of trace elements related to oxidative damage in Alzheimer's disease brain. They have found that a statistically significant elevation of iron and zinc was observed in multiple regions of brain of Alzheimer's and compared with controls. The levels of mercury were very high in Alzheimer's. The levels of selenium were also significantly elevated. The elevation of iron and zinc in Alzheimer's has the potential of augmenting neuron degeneration through the free radical process.

Huseyin, V. et al. [106] have studied alterations of plasma magnesium, copper, zinc, iron and selenium concentrations and some related to erythrocyte antioxidant enzyme activities in patients with Alzheimer's disease. They have found that plasma Mg, $\mathrm{Cu}, \mathrm{Zn}, \mathrm{Fe}$ and Se levels were lower in Alzheimer's compared to normal controls. Their results suggest that alterations in essential trace elements play a role in the etiopthogenesis of Alzheimer's also. There is a defect in the antioxidant defense system. It may lead to oxidative damage in Alzheimer's.

Asheley, I. B. et al. [107] have studied the role of zinc in the cerebral deposition of A $\beta$ amyloid in Alzheimer's disease. A $\beta$ is a 39 - 43 amino acid peptide that polymerizes within extracellular amyloid deposits in the necrophil and cerebral blood vessels in Alzheimer's disease and Down's syndrome. Wenstrup, D. et al. [108], Cantantindis, J. [109] and Corrigan, F. M. et al. [110] observed and found 10 that the zinc metabolism is altered in Alzheimer's disease and Down's syndrome. These observations show that there is a decrease pattern found in temporal lobe zinc levels.

Hershey, C. O. et al. [111] have studied eighty percent elevated zinc levels in cerebrospinal fluid of Alzheimer's. Lui, E. et al. [112] have studied hepatic zinc levels and found an increased hepatic zinc values with reduced zinc bound to metallothianein. Brackstran, J. R. et al. [113] have studied and found that an increase in extracellular $\mathrm{Zn}^{2+}$ metalloproteinase activities in Alzheimer's hippocampus. Uchida, Y. et al. [114] have studied and found decreased levels of astrocytic growth-inhibitory factor, which is a metallothicoein like protein chelates zinc. Franceschi, C. et al. [115] have studied and found that the zinc deficiency is a common, pervasive yet cryptogenic phenomenon in Down syndrome.

Bjorksten, B. et al. [116] have studied the zinc manifestations as immune dysfunction. Napolitanio, G. et al. [117] have studied the growth and delay with the supplementation of zinc in Down syndrome. Crapper Mc Lachlan, D. R. et al. [118] have been applied a therapy with a drug called desferrioxamine which chelates aluminum, iron and zinc and found that it is very effective in arresting the progression of dementia in Alzheimer's disease. Frederiseksan, C. J. et al. [119] have studied the critical region for memory function called hippocampus and found that this region contains highest concentrations of zinc in the body.

Frederickson, C. J. [120] has studied the extreme fluctuations of extracellular zinc levels such as (0.15 - 300 $\mu \mathrm{M})$. The physiological purpose of such high zinc concentrations in the hippocampus is not clear. Choi, D. W. et al. [121] have proposed that large trans-synaptic movement of zinc may have a normal signaling function. Stewart, G. R. et al. [122] have studied a prominent neurochemical deficit in Alzheimer's disease is cholinergic deafferentation of the hippocampus, due to which a rise in zinc concentration has reached in this region. Hyman, B. T. et al. [123] have studied and found that the certical vasculatures which contain an intraluminal zinc concentration of $20 \mu \mathrm{M}$, but the perivascular interstitial zinc concentration is $0.15 \mu \mathrm{M}$. These are the sites of high zinc concentration gradients and are severely and consistently affected by the pathological lesions of Alzheimer's disease. An abnormality of the homeostatic mechanisms, which handle high zinc fluxes, may explain the pathological features found in these separate anatomical sites in the Alzheimer's brains. Hicks, M. et al. [124] have studied serum plasma levels of copper and zinc in several cases of Alzheimer's disease and compared them with controls and found that there is no consensus on the nature of any differences, but estimations of blood zinc would be confounded by many variables which would make zinc levels inconsistent. Pohit, J. et al. [125] have studied plasma zinc levels and found these levels rise postprandially. Sandström, B. et al. [126] have studied the absorption of zinc and found that the absorption is affected by the presence of so many dietary elements such as proteins, fiber and sugar. Burnet [127] has suggested that a deficiency of zinc may play an interesting and very amaging role in the aged people with Alzheimer's disease. Markesbery, W. R. et al. [128] have found that brain zinc levels remain relatively constant throughout adult life. Ehmann, W. D. et al. [129] have studied that zinc is most abundant in the hippocampus. Ehmann, W. D. et al. [130] have found that concentrations of zinc in the hippocampus of Alzheimer's disease patients and controls were not significantly different. Thompson, C. M. et al. [131] have shown that mean zinc levels in the amygdala were significantly elevated in Alzheimer's disease 
persons in comparison to healthy controls. Harshey et al. [132] have found that there is no significant difference in zinc levels in the frontal and temporal cortices in Alzheimer's disease persons and controls. Markesbery, W. $\mathrm{R}$ et al. [133] have given a detailed study on the brain trace elements in Alzheimer's disease and concluded that an efficient homeostatic mechanism maintains the concentration of zinc in a normal rage in the brain of Alzheimer's disease persons.

Goodman, L. [134], Good, P. F. et al. [135], Andorn, M. C. et al. [136] and Connor, J. R. et al. [137] have suggested a disturbance of iron metabolism in the brain of Alzheimer's disease persons, Goodman, L. [134] found that there was an increasing pattern in the cortex of Alzheimer's. This disease may be due to a disruption of the cerebral metabolism of iron. Commor, J. R. et al. [137] have performed histochemical staining for iron and confirmed that the iron was present in S. P. and in cells associated with S.P. Immuno reactivity of transferrin was found to be homogenously distributed around S. P in Alzheimer's disease and in astrocytes in cerebral white matter in Alzheimer's rather than aligadendroglia Ehmann, et al. [138] have studied the bulk cortical samples and found that iron was slightly higher on a freeze dry weight basis in Alzheimer's disease as (345 \pm 0.00$)$ $\mu \mathrm{g} / \mathrm{g}$ and in controls as $(311 \pm 0.0) \mu \mathrm{g} / \mathrm{g}$. The specimens of separated cerebral gray and while matter revealed higher total mean iron levels in Alzheimer's disease gray matter as $(467 \pm 0.0) \mu \mathrm{g} / \mathrm{g}$ than in controls $(280 \pm 0.0)$ $\mu \mathrm{g} / \mathrm{g}$. Alzheimer's disease white matter contained more iron than controls i.e. $(202 \pm 0.0) \mu \mathrm{g} / \mathrm{g}$ and $(145 \pm 0.0)$ $\mu \mathrm{g} / \mathrm{g}$ respectively. The mean iron values were also studied in the amygdala of Alzheimer's and compared with normals as (306 \pm 0.0$) \mu \mathrm{g} / \mathrm{g}$ and $(256 \pm 0.0) \mu \mathrm{g} / \mathrm{g}$ respectively. Mean iron levels were also reported as a tendency of elevation in the hippocampus and nucleus basalis of Meynert (nbM) in Alzheimer's disease patients than in controls.

Fleminy, J. et al. [139] have isolated ferritin from brain of patients of Alzheimer's disease and found that there are higher levels of iron in comparison to controls. Switzer, R. C. et al. [140] have studied and traced iron and ferritin in S P and Alzheimer's disease patients. Grundke-Iqbal, I. et al. [141] have studied ferritin immuroreactivity and was found to accumulate in microglia in association with S.P and Alzheimer's disease. Coonor, J. R. et al. [142] have reported that transferrin immuno reactivity was present in normal individuals.

Several research reports suggest that calcium homeostasis is altered in fibroblasts from Alzheimer's disease patients. Sherrington, R. et al. [143] have reported that the abnormal gene in the majority of Alzheimer's families is related to calcium cycling within the cellular organelles. Peterson, C. et al. [144] have reported a reduced uptake of $\mathrm{Ca}^{43}$. It is very difficult to say that a consistently altered response to stimulation occurs in Alzheimer's disease fibroblasts. Ito, E. et al. [145] have shown enhanced sensitivity of $\left[\mathrm{Ca}^{2+}\right]_{\mathrm{i}}$ to bombesin in Alzheimer's disease fibroblasts. Peterson, C. et al. [146] and Peterson, C. et al. [147] and have shown a trend of decrease in calcium. Chakrobarty, S et al. [148] have studied early calcium dysregulation in Alzheimer's disease. They have reported that increased intracellular calcium levels are functionally linked to presenilemutuations, Apo E4expression, amyloid plaques, tau tangles and synaptic dysfunction. Mc Coy, K. R. et al. [149] have shown an increase in calcium in Alzheimer's disease. Huang, H. M. et al. [150] and Borden, L. A. et al. [151] have found that there is no change in calcium in Alzheimer's disease. Khachaturian, Z. S. [152] and Mattson, M. P. [153] have given their finding on the calcium as the calcium may play a major role in neuron death in aging and Alzheimer's disease. It is very difficult to analyze with the specimens of postmortem of Alzheimer's disease persons by the available instrumental facilities. Can Zoniero, L. M. et al. [154] have studied the calcium in Alzheimer's disease pathogenesis and reported that there is a possibility for some of the neuronal death observed in Alzheimer's disease might be associated with a reduction in rather than an increase in cytosolic $\mathrm{Ca}^{2+}$ levels.

Martyn, C. M. et al. [155] have studied calcium metabolism in Alzheimer's disease and found that evidence linking aluminum absorption to calcium metabolism prompted a case-control study of physiological markers of calcium homeostasis in the patients. Mean plasma 25-hydroxy-vitamin D concentration was found to be very low in comparison to healthy controls.

Mattson, M.P. et al. [156] have studied neuronal and glial calcium signaling in Alzheimer's disease and found that there are some abnormalities in calcium regulation in astrocytes, oligodendrocytes and microglia found in studies of experimental model of Alzheimer's disease. They have given their thoughts as the perturbed cellular calcium homeostasis may play a prominent role in the pathogenesis of Alzheimer's disease.

Woods, N. K. et al. [157] have studied neuronal calcium signaling and Alzheimer's disease. They have found that altered calcium signalling differentially regulates genes such as calcineurin, calmodulin kinase II, M A P kinase etc. and induces protein modifications and neuritic degeneration. The functional synapses and synaptic transmission are fundamental processes in memory function. The alterations in these processes can lead to neu- 
ronal dysfunction and memory deficit.

Pascal, A. et al. [158] have studied calcium alterations in Alzheimer's disease and found that alterations in calcium homeostasis might be criticallyimplicated in brain aging and in the neuropathology of Alzheimer's disease. They have also reported that peripheral cell lines may represent a useful approach to explore the cellular pathophysiology of this disease.

Frank, M. L. [159] has studied calcium dyshomeastasis and intracellular signaling in Alzheimer's and found that destabilization of calcium signalling seems to be central to the pathogenesis of Alzheimer's disease.

Bojarski, L. et al. [160] have studied calcium dysregulation in Alzheimer's disease and put forward their suggestions as the dysregulation of calcium homeostasis may be a key factor in accelerating other pathological changes.

Berridge, M. J. [161] studied calcium hypothesis in Alzheimer's disease .Author proposed the calcium hypothesis and explored activation of amyloidogenic pathway. It may function to remodel the neuronal $\mathrm{Ca}^{2+}$ signaling pathways responsible for cognition. Cilliler, A. E. et al. [162] have studied serum magnesium level and clinical deterioration in Alzheimer's disease and found that a significant difference for magnesium levels. They have found a negative correlations between magnesium levels and GDS and CDR (respectively $r=-0.35, p=$ $0.033, r=-0.360$ and $p=0.029$ ).

Ali, S. S. et al. [163] have studied serum magnesium levels in Alzheimer's disease and found that the levels were $(1.7 \pm 0.2) \mathrm{ppm}$ and $(1.8 \pm 0.3) \mathrm{ppm}$. These levels were significantly lower in Alzheimer's disease. There was no meaningful relationship found between magnesium levels and severity of the disease.

Durlach, J. [164] has studied magnesium depletion and pathogenesis of Alzheimer's disease and found that magnesium depletion appears to be an important pathogenic factor in this disease.

Glick, J. L. [165] has also studied the role of magnesium and found that Alzheimer's disease involves a defective transport process characterized by both abnormally low magnesium incorporation and abnormally high aluminum incorporation into brain neuro. Author has studied the levels of magnesium and found that on the basis of statistical analysis a significant decrease in the frequency of intracellular magnesium deposits in neurons of Alzheimer's disease patients as compared with controls. Korf, J. et al. [166] have studied magnesium, potassium and glutamic acid in hippocampal a tissue of the patients of Alzheimer's disease.

Barbagallo, M. et al. [167] have studied the magnesium homeostasis in patients with mild to moderate Alzheimer's disease. They have analysed blood samples for serum total magnesium (Mg-tot) and serum ionised magnesium (Mg-ion) and found that $(20.5 \pm 0.7) \mathrm{m} \mathrm{mol} / \mathrm{l}$ as Mg-tot and $(27.9 \pm 0.2) \mathrm{m} \mathrm{mol} / \mathrm{l}$ as Mg-ion in Alzheimer's disease. They have measured the same categories of magnesium in controls and given the data as $(0.50$ $\pm 0.01) \mathrm{m} \mathrm{mol} / \mathrm{l}$ and $(0.53 \pm 0.01) \mathrm{m} \mathrm{mol} / \mathrm{l}$.

Mielke, M. M. et al. [168] have studied low serum potassium in mild life associated with decreased cerebrospinal fluid A beta 42 in late life and suggested that serum potassium is a modifiable risk factor and further examination of the potassium-dementia relationship is warranted. It has been reported in the literature that antihypertensive, particularly potassium sparing diuretics can reduce the risk of dementia including Alzheimer's disease.

Klater pills diuretics flush excess water and sodium from the body while avoiding excretion of potassium. The importance of maintaining sufficient amounts of potassium in systemic circulation to prevent Alzheimer's disease is very necessary. Low serum potassium levels in the mid life increase the risk of high blood pressure and strok-cardiovascular factors that also increased the risk of Alzheimer's disease. Serum potassium can be readily modified by diet.

Diebel, M. A. et al. [169] have studied copper, iron and Zinc imbalances in severely degenerated brain regions in Alzheimer's disease: possible relation to oxidative stress and found that a significant decrease in copper and significant increase in zinc and iron were noted in hippocampus and amygdala areas.

Huseyin, V. et al. [170] have studied alterations of plasma magnesium, copper, zinc, iron and selenium concentrations and some related erythrocyte antioxidants enzyme activities in patients of Alzheimer's disease. They have reported their findings as plasma, magnesium, copper, zinc, iron and selenium levels were found to be significantly lower patients with Alzheimer's disease compared with controls. Alterations in trace elements may play a role in the eticpathogenesis of this disease.

There are specific cellular and neurochemical alterations in the brain of Alzheimer's disease. The difficulty is in the detecting these changes. There are

It has been established in the literature that the AAS throw light and give information regarding the number of 
gaseous metal atoms remain in the ground state normally. These ground state atoms are more capable of absorbing radiant energy of their own specific resonance wavelength. The light of resonance wavelength is passed through a flame containing the atoms, then some part of the light will be absorbed. The extend of absorption is proportional to the number of ground state atoms present in the flame. The atomic absorption spectroscopy is based on the same principle as the flame some factors which could contribute to the changes in the brain of this neurological disorder. This disease could be caused by on environmental toxin. Philips, G. S. [171] has shown that Alzheimer's disease is more common in western countries than Japan and the developing countries.

Mattiello, G. et al. [172] have studied micro elemental analysis from Alzheimer's and multi infarctual dementia patients and reported that micro elemental medicine represents a new inter disciplinary field that is more than a simple presentation of analytical data. Analytical findings must be carefully integrated with other parameters such as biochemical, clinico-chemical and others also to give a more global view. Authors have also detected some trace elements in Alzheimer's disease and multi imfaretual dementia and compared with normals. They have measured Al, As, Ca, Co, Cs, Cu, Fe, Hg, Li, Mg, Pb, Se, Sr, and Zn. Crapper-McLathlan, D. R. [173] studied and reported as among the different hypothesis on the origin of the pathology of Alzheimer's disease is that involving mineral element dysmetabolism. This type of dysmetabolism may be a consequence of the disease or a relevant factor in its pathogenesis.

Cornett, C. R. et al. [174] have studied trace elements in Alzheimer's disease pituitary glands and found that the levels of Selenium, iron, rubidium mercury and zinc could not show any significant difference between these elements and controls.

\section{Basic Theory of Flame Atomic Absorption Spectroscopy}

Walsh, A [175] has proposed the phenomenon of atomic absorption in 1802 for the quantitative analysis of elements. Skoog et al. [176] have supplied relevant information about this technique in detail. Atomic absorption analysis involves measuring the absorption of light by vaporized ground state atoms and relating the absorption to concentration. The incident beam of light is attenuated by atomic vapour absorption according to Beer's Law. The instrumental and chemical parameters of the system must be geared towards the production of neutral ground state atoms of the proposed element for study. The conversion of sample from its native state to the atomic state can be achieved by using a method called flame atomic absorption spectroscopy (AAS) or an electric furnace. The sample undergoes a number of pretreatment steps prior to analysis in the furnace.

The sample is dried by evaporating the solvent in the first step. The organic matrix is decomposed by heating the sample in the second step. The heating temperature may go upto $1000^{\circ} \mathrm{C}$. Ultimately the furnace is rapidly heated to a temperature around $2400^{\circ} \mathrm{C}$ to produce vaporized neutral atoms with as many as possible in their electronic ground states.

\section{Materials and Methods}

Blood sample of Alzheimer's disease patients along with normal healthy control were collected from the Department of Neurology, Safdarjang Hospital, New Delhi-110016 after the approval of ethical committee of the hospital. $10 \mathrm{ml}$ freshly drawn blood from each patient was collected in clean and dry test tube without any anti-coagulant. The test tube was kept for 45 minutes at room temperature $\left(22^{\circ} \mathrm{C} \pm 2^{\circ} \mathrm{C}\right)$ for the formation of clot. Sera of different patients were separated by centrifugation at 1500 r.p.m. upto 15 minutes and were collected in screw capped test tubes.

The atomic absorption spectral estimation of the serum samples from normal persons and Alzheimer's disease patients were carried out on atomic absorption spectrophotometer Model No. AA-6300 of Shimadzu Japan, at Department of Environmental study University of Delhi 110007.

\section{Results}

We have measured the values of trace elements such as $\mathrm{Cu}, \mathrm{Fe}, \mathrm{Zn}, \mathrm{Na}, \mathrm{K}, \mathrm{Ca}, \mathrm{Al}$ and $\mathrm{Mg}$, in Alzheimer's disease patients and healthy normal control given in Table 1 along with the latest availability of the literature.

Regression coefficient and multiple correlation coefficients were also given is the Table 2 and Table 3.

\section{Discussion}

The estimation of trace elements show a colorful presentation of different metals. It has been seen and found that 
Table 1. Results along with work carried out by researchers on different mode of analysis using different types of samples and diseases.

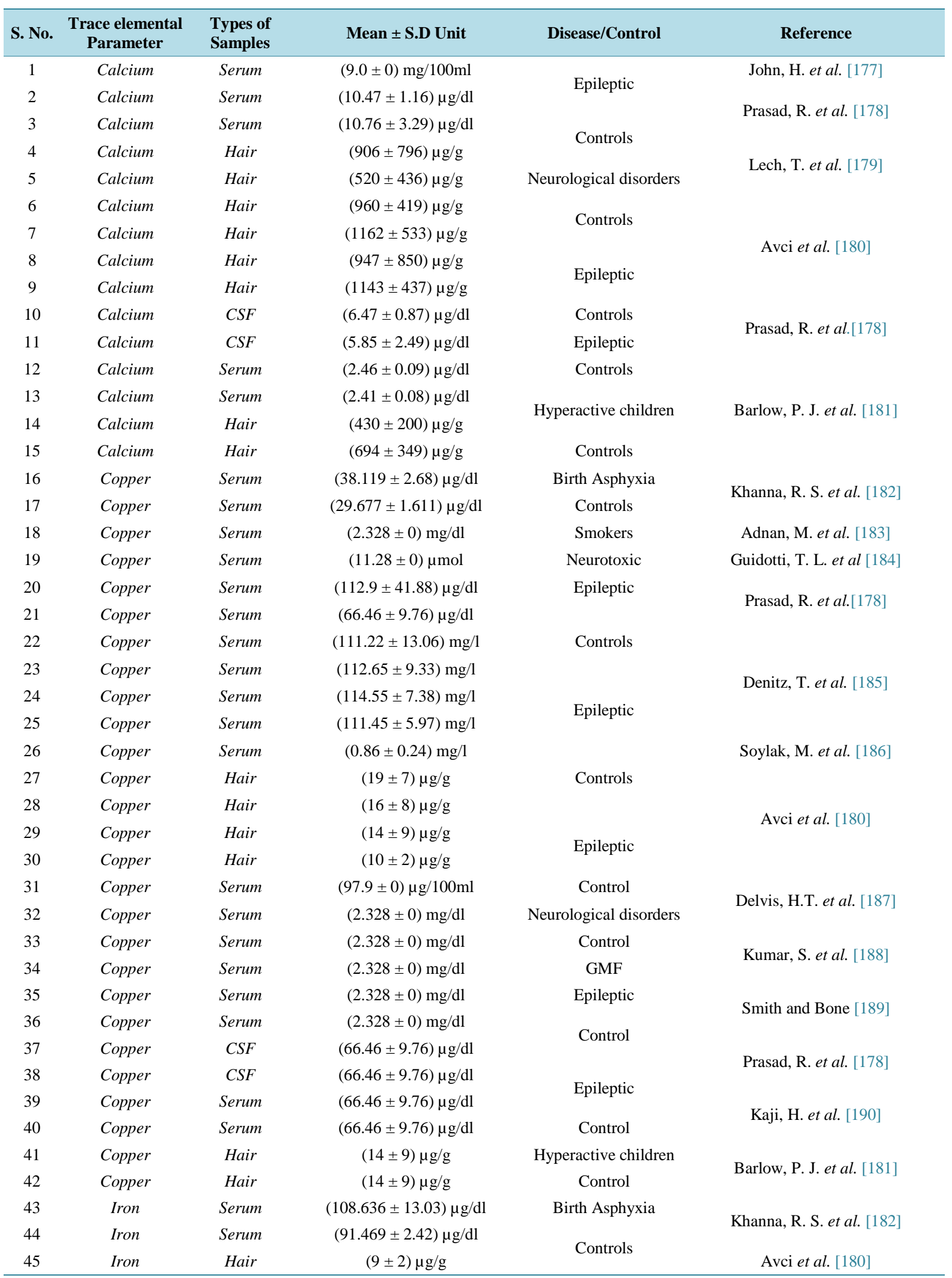




\section{Continued}

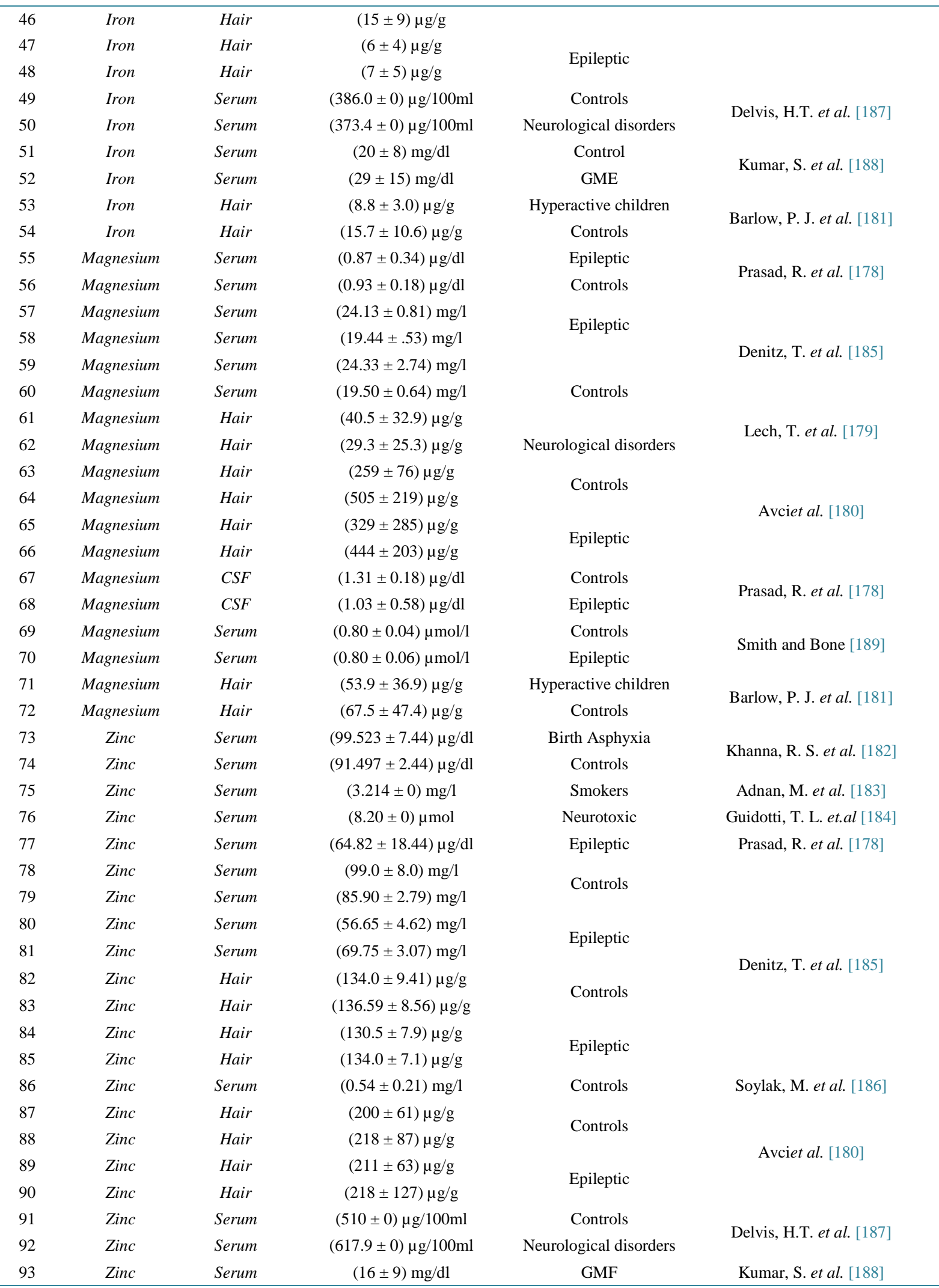




\section{Continued}

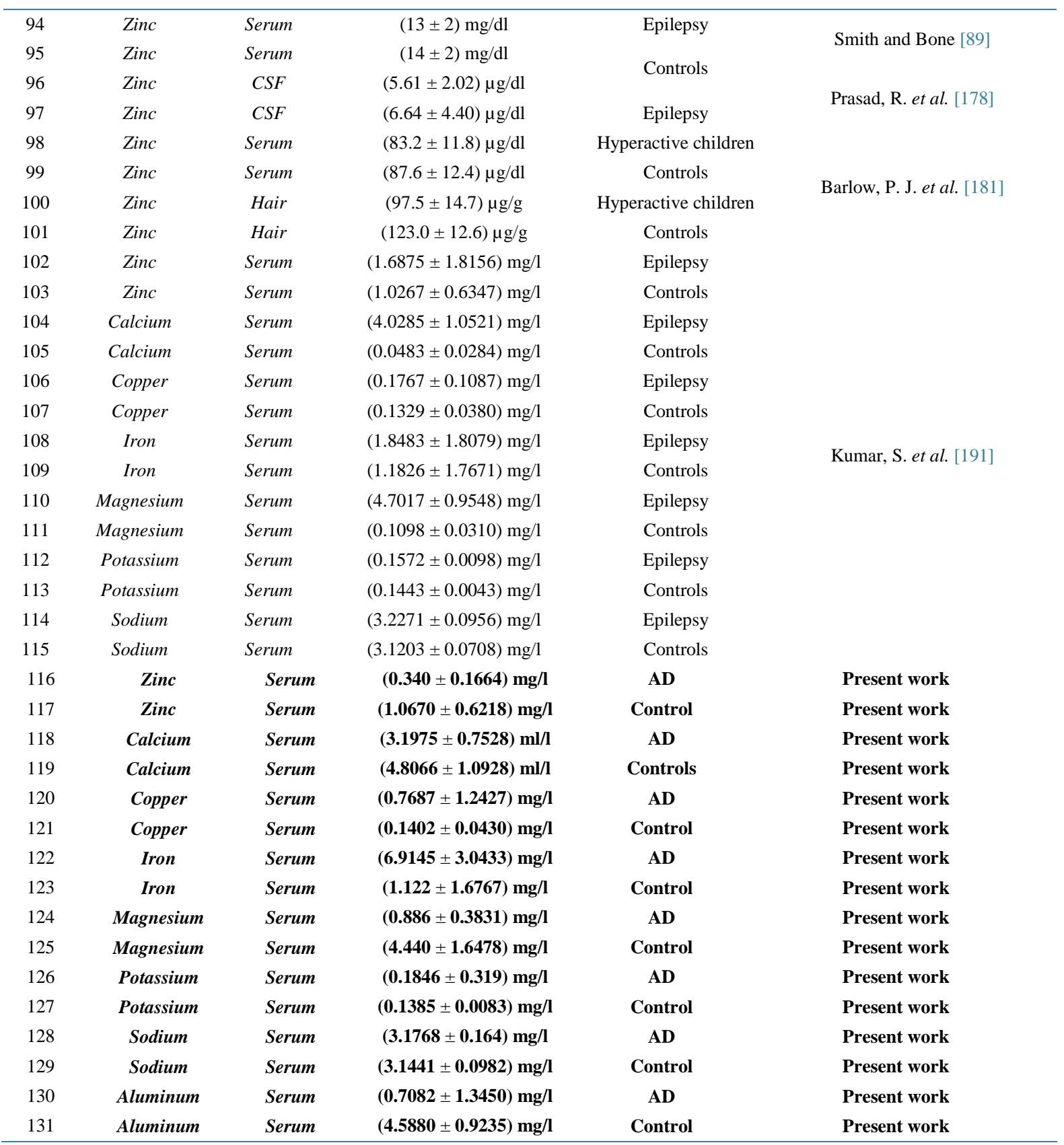

the levels of zinc, calcium, magnesium, aluminum were lower in Alzheimer's disease samples in comparison to healthy controls. The elements such as copper, Iron, potassium and sodium were found higher than controls.

On the basis of statistical analysis we have measured regression and correlation coefficients including Multiple correlation coefficients between different trace elements like $\mathrm{Na}, \mathrm{K}, \mathrm{Ca}, \mathrm{Mg}, \mathrm{Zn}, \mathrm{Cu}, \mathrm{Fe}$ and $\mathrm{Al}$ in normal samples.

A trend has been found in coefficient of correlation such as $r_{\text {Ca.Mg }}>r_{\text {Na.K }}>r_{\text {Cu.Zn }}>r_{\text {Zn.Al }}>r_{\text {Cu.Fe }}>$ $r_{\text {Cu.Al }}$ with positive correlation and $r_{\text {Fe.Al }}>r_{\text {Fe.Zn }}$ with negative correlation.

Coefficient of partial correlation is also calculated and found that a trend has been set up between trace elements and given here as $r_{\text {NaK.Mg }}>r_{\text {ZnCu.Fe }}>r_{\text {NaK.Ca }}>r_{\text {CuFe.Zn }}$ with positive correlation and $r_{\text {ZnF.Cu }}>r_{\text {ZnFe.Al }}>$ 
Table 2. Regression and correlation coefficient studies on $\mathrm{Na}, \mathrm{K}, \mathrm{Ca}, \mathrm{Mg}, \mathrm{Zn}, \mathrm{Cu}$, Fe and Aluminum in normal samples.

\begin{tabular}{|c|c|c|c|c|c|c|}
\hline Diagnosis & Regression coefficients & Regression equations & $\begin{array}{l}\text { Coefficient of } \\
\text { correlation }\end{array}$ & $\begin{array}{l}\text { Coefficient of } \\
\text { partial correlation }\end{array}$ & $\begin{array}{r}\text { Multiple } \\
\text { coe }\end{array}$ & $\begin{array}{l}\text { correlation } \\
\text { ficient }\end{array}$ \\
\hline \multirow{14}{*}{ Normal } & $b_{\mathrm{Na.K}}=4.0818$ & \multirow{2}{*}{$\begin{array}{l}\mathrm{Na}=4.0818 \mathrm{~K}+2.5787 \\
\mathrm{~K}=0.0291 \mathrm{Na}+0.0470\end{array}$} & \multirow{2}{*}{$r_{\mathrm{Na} . \mathrm{K}}=0.345$} & $r_{\text {CaNa.K }}=-0.2029$ & $R_{\mathrm{Na} . \text { KCa }}$ & $=0.1553$ \\
\hline & $b_{\mathrm{K} . \mathrm{Na}}=0.0291$ & & & $r_{\text {CaK.Na }}=-0.0411$ & $R_{\text {K.NaCa }}$ & $=0.1206$ \\
\hline & $b_{\text {Ca.Mg }}=0.5180$ & \multirow{2}{*}{$\begin{array}{c}\mathrm{Ca}=0.5180 \mathrm{Mg}+2.5066 \\
\mathrm{Mg}=1.179 \mathrm{Ca}-1.2216\end{array}$} & \multirow{2}{*}{$r_{\text {Ca.Mg }}=0.7812$} & $r_{\text {NaK.Ca }}=0.3286$ & $R_{\text {С.KNa }}$ & $=0.0978$ \\
\hline & $b_{\mathrm{Mg} . \mathrm{Ca}}=1.1779$ & & & $r_{\mathrm{MgNa} . \mathrm{K}}=-0.2459$ & $R_{\mathrm{Mg} \text {.NaK }}$ & $=0.0939$ \\
\hline & $b_{\mathrm{Mg}, \mathrm{Ca}}=0.0029$ & \multirow{2}{*}{$\begin{array}{l}\mathrm{Cu}=0.0029 \mathrm{Fe}+0.1369 \\
\mathrm{Fe}=4.4335 \mathrm{Cu}+0.5007\end{array}$} & \multirow{2}{*}{$r_{\text {Cu.Fe }}=0.1137$} & $r_{\text {MgK.Na }}=-0.0979$ & $R_{\mathrm{Na} \cdot \mathrm{MgK}}$ & $=0.1723$ \\
\hline & $b_{\mathrm{Fe} . \mathrm{Cu}}=4.4335$ & & & $r_{\text {NaK.Mg }}=0.4258$ & $R_{\mathrm{K} . \mathrm{MgNa}}$ & $=0.2104$ \\
\hline & $b_{\text {Cu.Zn }}=0.0192$ & \multirow{2}{*}{$\begin{array}{l}\mathrm{Cu}=0.0192 \mathrm{Zn}+0.1197 \\
\mathrm{Zn}=4.0171 \mathrm{Cu}+0.5038\end{array}$} & \multirow{2}{*}{$r_{\text {Fe.Zn }}=-0.4280$} & $r_{\text {ZnCu.Fe }}=0.3955$ & $R_{\text {Cu.Fezn }}$ & $=0.1689$ \\
\hline & $b_{\mathrm{zn} \cdot \mathrm{Cu}}=4.0171$ & & & $r_{\text {ZnFe.Cu }}=-0.5439$ & $R_{\mathrm{Fe} . \mathrm{CuZn}}$ & $=0.3062$ \\
\hline & $\begin{aligned} b_{\text {Fe.Zn }} & =-1.1541 \\
h & =-0.1587\end{aligned}$ & $\begin{array}{l}\mathrm{Fe}=-1.1541 \mathrm{Zn}+2.3538 \\
\mathrm{Zn}=-0.1587 \mathrm{Fe}+1.2451\end{array}$ & \multirow[t]{2}{*}{$r_{\mathrm{Cu} . \mathrm{Zn}}=0.2778$} & \multirow[t]{2}{*}{$r_{\text {Cufe.Zn }}=0.3088$} & \multirow[t]{2}{*}{$R_{\text {zn.FeCu }}$} & \multirow[t]{2}{*}{$=0.4535$} \\
\hline & $D_{\text {Zn.Fe }}=-0.158 /$ & $211=0.150 / 10+1.2401$ & & & & \\
\hline & $b_{\mathrm{zn} . \mathrm{Al}}=0.1772$ & \multirow{4}{*}{$\begin{array}{l}\mathrm{Zn}=0.1772 \mathrm{Al}+0.2540 \\
\mathrm{Al}=0.3909 \mathrm{Zn}+4.1709\end{array}$} & \multirow{2}{*}{$r_{\text {Zn.Al }}=$} & \multirow{4}{*}{$r_{\text {ZnFe.Al }}=-0.4788$} & \multirow{4}{*}{$R_{\text {Zn.FeAl }}$} & \multirow{4}{*}{$=0.2826$} \\
\hline & $b_{\mathrm{AlZn}}=0.3909$ & & & & & \\
\hline & & & $r_{\text {Fe.Al }}=-0.856$ & & & \\
\hline & & & $r_{\text {Cu.Al }}=0.0981$ & & & \\
\hline
\end{tabular}

Table 3. Regression and correlation coefficient studies on $\mathrm{Na}, \mathrm{K}, \mathrm{Ca}, \mathrm{Mg}, \mathrm{Zn}, \mathrm{Cu}$, Fe and Aluminum in Alzheimer's samples.

\begin{tabular}{|c|c|c|c|c|c|}
\hline Diagnosis & Regression coefficients & Regression equations & $\begin{array}{l}\text { Coefficient of } \\
\text { correlation }\end{array}$ & $\begin{array}{c}\text { Coefficient of } \\
\text { partial correlation }\end{array}$ & $\begin{array}{l}\text { Multiple correlation } \\
\text { coefficient }\end{array}$ \\
\hline \multirow{14}{*}{ Normal } & $b_{\mathrm{Na} . \mathrm{K}}=6.0045$ & $\mathrm{Na}=6.0045 \mathrm{~K}+2.2559$ & \multirow{2}{*}{$=0.3355$} & $r_{\text {CaNa.K }}=-0.2418$ & $R_{\mathrm{Na} \text {.KСa }}=0.1584$ \\
\hline & $b_{\mathrm{K} . \mathrm{Na}}=0.0187$ & $K=0.0187 \mathrm{Na}+0.1216$ & & $r_{\text {СаK.Na }}=-0.2361$ & $R_{\mathrm{K} . \mathrm{NaCa}}=01566$ \\
\hline & $b_{\text {C..Mg }}=0.3597$ & \multirow{2}{*}{$\begin{array}{l}\mathrm{Ca}=0.3597 \mathrm{Mg}+2.8788 \\
\mathrm{Mg}=0.0924 \mathrm{Ca}+0.5905\end{array}$} & \multirow{2}{*}{$=0.1824$} & $r_{\text {NaK.Ca }}=0.2611$ & $R_{\text {Ca.KNa }}=01493$ \\
\hline & $b_{\mathrm{Mg} . \mathrm{Ca}}=0.0924$ & & & $r_{\mathrm{MgNa} . \mathrm{K}}=-0.0894$ & $R_{\mathrm{Mg} \text {.NaK }}=0.00619$ \\
\hline & $b_{\text {Cu.fe }}=0.1532$ & $\mathrm{Cu}=0.1532 \mathrm{Fe}-0.2906$ & \multirow{2}{*}{$=0.3753$} & $r_{\mathrm{MgK.Na}}=0.0267$ & $R_{\text {Na.MgK }}=01197$ \\
\hline & $b_{\mathrm{Fe} . \mathrm{Cu}}=0.9190$ & $\mathrm{Fe}=0.9190 \mathrm{Cu}+6.2081$ & & $r_{\text {NaK.Mg }}=0.3423$ & $R_{\mathrm{K} . \mathrm{MgNa}}=0.1131$ \\
\hline & $b_{\text {Cu.Zn }}=2.2008$ & \multirow{2}{*}{$\begin{array}{c}\mathrm{Cu}=-2.2008 \mathrm{Zn}+1.5791 \\
\mathrm{Zn}=-0.04 \mathrm{Cu}+0.3717\end{array}$} & \multirow{2}{*}{$=0.3120$} & $r_{\text {ZnCu.Fe }}=-0.4734$ & $R_{\text {Cu.Fezn }}=0.2510$ \\
\hline & $b_{\mathrm{zn} \text {.Сu }}=-0.0400$ & & & $r_{\text {ZnFe.Cu }}=0.4843$ & $R_{\mathrm{Fe} . \mathrm{CUZn}}=0.3580$ \\
\hline & $\begin{aligned} b_{\mathrm{Fe} . \mathrm{Zn}} & =5.6655 \\
b & =0.017\end{aligned}$ & $\begin{array}{l}\mathrm{Fe}=5.6655 \mathrm{Zn}+4.926 \\
\mathrm{Zn}=0.017 \mathrm{Fe}+0.2234\end{array}$ & \multirow[t]{2}{*}{$r_{\text {Cu.Zn }}=-0.2968$} & \multirow[t]{2}{*}{$r_{\text {CuF.Zn }}=0.5184$} & \multirow[t]{2}{*}{$R_{\text {Zn.FeCu }}=0.2967$} \\
\hline & $b_{\mathrm{Zn.Fe}}=0.017$ & & & & \\
\hline & $b_{\text {Zn.Al }}=0.460$ & $\mathrm{Zn}=0.460 \mathrm{Al}+0.01422$ & \multirow{2}{*}{$r_{\text {Zn.Al }}$} & \multirow{4}{*}{$r_{\text {ZnFe.Al }}=0.2921$} & \multirow{4}{*}{$R_{\text {Zn.FeAl }}=0.0852$} \\
\hline & $b_{\mathrm{AlZn}}=3.0100$ & $\mathrm{Al}=3.0100 \mathrm{Zn}-0.3152$ & & & \\
\hline & & & $r_{\text {Fe.Al }}=0.1157$ & & \\
\hline & & & $r_{\text {Cu.AI }}=-0.2376$ & & \\
\hline
\end{tabular}

$r_{\mathrm{MgNa} . \mathrm{K}}>r_{\mathrm{CaNa.K}}>r_{\mathrm{MgK} . \mathrm{Na}}>r_{\mathrm{CaK} . \mathrm{Na}}$ with negative correlation.

Multiple correlation coefficient in normal healthy person has been estimated and found that a trend, which is 
given here as

$$
R_{\mathrm{Zn.FeCu}}>R_{\mathrm{Fe} . \mathrm{CuZn}}>R_{\mathrm{Zn.FeAl}}>R_{\mathrm{K} . \mathrm{MgNa}}>R_{\mathrm{Na} . \mathrm{MgK}}>R_{\mathrm{Cu} . \mathrm{FeZn}}>R_{\mathrm{Na} . \mathrm{KCa}}>R_{\mathrm{K} . \mathrm{NaCa}}>R_{\mathrm{Ca} . \mathrm{KNa}}>R_{\mathrm{Mg} . \mathrm{NaK}} .
$$

We have also measured correlation coefficients including multiple correlation coefficient between different types of trace elements like $\mathrm{Na}, \mathrm{K}, \mathrm{Ca}, \mathrm{Mg}, \mathrm{Zn}, \mathrm{Cu}, \mathrm{Fe}$ and Aluminum in $\mathrm{AD}$ samples.

A trend has been found in coefficient of correlation such as $r_{\text {Cu.Fe }}>r_{\mathrm{Zn.Al}}>r_{\mathrm{Na} . \mathrm{K}}>r_{\mathrm{Ca} . \mathrm{Mg}}>r_{\mathrm{Fe} . \mathrm{Al}}$ with positive correlation and $r_{\mathrm{Cu} . \mathrm{Zn}}>r_{\mathrm{Cu} . \mathrm{Al}}$ with negative correlation.

Coefficient of partial correlation is also calculated and found that a trend has been set up between trace elements and given here as $r_{\text {CuFe.Zn }}>r_{\text {ZnFe.Cu }}>r_{\text {NaK.Mg }}>r_{\text {ZnFe.Al }}>r_{\text {NaK.Ca }}>r_{\text {MgK.Na }}$ with positive correlation and $r_{\text {ZnCu.Fe }}>r_{\text {CaNa.K }}>r_{\text {CaK.Na }}>r_{\text {MgNa.K }}$ with negative correlation

Multiple correlation coefficient in $\mathrm{AD}$ samples have been estimated and found that a trend, which is given here as

$$
R_{\mathrm{Fe} . \mathrm{CuZn}}>R_{\mathrm{Zn} . \mathrm{FeCu}}>R_{\mathrm{Cu} . \mathrm{FeZn}}>R_{\mathrm{Na} . \mathrm{KCa}}>R_{\mathrm{K} . \mathrm{NaCa}}>R_{\mathrm{Ca} . \mathrm{KNa}}>R_{\mathrm{Na} . \mathrm{MgK}}>R_{\mathrm{K} . \mathrm{MgNa}}>R_{\mathrm{Zn} . \mathrm{FeAl}}>R_{\mathrm{Mg} . \mathrm{NaK}} \cdot
$$

\section{Conclusions}

It is very well documented that the chemical form of trace element and interactions between different types of trace elements included in the food are very important in deciding between hazard and health.

The imbalance of the levels of these elements may be adjusted with the proper medication monitoring. Trace elements may act as catalytic agents for enzyme system of the cells. The minimum requirements of living objects for essential trace elements may be expressed in proportions or concentration of the total dry food taken every day. A tolerance of the human system may be adjusted according to intake of these elements. Tolerance is related to the immunity of our human system. If the tolerance is on the lower side of normalcy the immunity may be decreased. We must increase the immunity with the adjustment of proper food and supplementation of suitable trace elements.

Routine cocktail of medicines with side effects must avoid. We can take minerals, vitamins and essential fatty acids with proper trace elements for healthy human system. A continuous monitoring of trace elements in human tissues and fluids has led to legitimate concern about the probable effects of the presence of trace elements in human system. Our findings suggest that the values of higher levels of trace elements should be adjusted such that these levels must slight below or equal to the normal limits of the particular element. The elements such as copper, iron, potassium along with sodium must be adjusted up to the normalcy and keep the levels of the trace elements such as zinc, calcium, magnesium, aluminum within the normal limits.

\section{Acknowledgements}

Authors are thankful to Dr. P. K. Saxena Principal, D.A.V. (P.G.) College, Muzaffarnagar, U. P. for providing necessary conditions to carry research. We are thankful to Dr. M.K. Bansal, Hon'ble Secretary, D.A.V. (P.G.) College, Muzaffarnagar, U.P. for moral support in the present study. Authors are thankful to Mr. Sunil Kumar Sharma, Research Scientist, Department of Environmental study University of Delhi 110007 for providing the experimental facility of estimation of trace elemental analysis to us.

\section{References}

[1] Sambat, L. (1994) Historical Perspectives. In: Handy, R.C., Turnbull, J.M., Clark, W. and LanCaster, M.N., Eds., Alzheimer's Disease. A Hand Book for Care Givers, 2nd Edition, Mosby-Year, Book, Inc., St. Louis, 51-59.

[2] Reger, B. (2002) Alzheimer's Disease: A Brief History and Avenues for Current Research. Drew University, Madison, $1-5$.

[3] Whaley, N.S. (2002) Senility, Confusion, Debate Fear: Conceptualizing Alzheimer's Disease and the History of Senile Dementia. Thesis, Drew University, Madison.

[4] Rrown, C.B., Lockwood, A.H. and Sonawane, B.R. (2005) Neurodegenerative Disease: An Overview of Environmental Risk Factors. Environmental Health Perspectives, 113, 1250-1256. http://dx.doi.org/10.1289/ehp.7567

[5] Harry, V. and Jenaro, F. (2003) Alzheimer's Disease. In: Cummings, J.L. and Martin, D., Eds., Neuropsychiatry of Alzheimer's Disease and Related Dementias, CRC Press, Boca Raton, 57-116. 
[6] Lindy, E.H., Daniel, M., Linda, D., Jane, F., Sheila, B., Anderson, B., Chaterjee, A. and Bartolucci, A. (1995) Behavioral Changes in Early Alzheimer's Disease. In: Iqbal, K., Martimer, J.A., Winblad, B. and Wisniewski, H.M., Eds., Research Advances in Alzheimer's Disease and Related Disorders, John Wiley \& Sons, Hoboken, 219-224.

[7] Robins, P.V., Mace, N.L. and Lucas, M.J. (1982) The Impact of Dementia on the Family. JAMA, 248, 333-335. http://dx.doi.org/10.1001/jama.1982.03330030039022

[8] Folstein, M. and Bylsma, F.W. (1994) Non Cognitive Symptoms of Alzheimer’s Disease. In: Terry, R., Katzman, R. and Beck, K.C., Eds., Alzheimer's Disease, Raven Press, New York, 27-40.

[9] Reisberg, B., Borenstein, J., Salob, S.P., Ferris, S.H., Franssen, E. and Georgotas, A. (1987) Behavioral Symptoms in Alzheimer's Disease: Phenomenology and Treatment. Journal of Clinical Psychiatry, 48, 9-15.

[10] Teri, L., Larson, E. and Reixer, B. (1988) Behavioral Disturbance in Dementia of the Alzheimer's Type. Journal of the American Geriatrics Society, 36, 1-6.

[11] Berrios, G.E. and Brook, P. (1985) Delusions and the Psycholothology of the Elderly with Dementia. Acta Psychiatrica Scandinavica, 72, 296-301.

[12] Cummings, J.L. (1985) Organic Delusions Phenomenology, Anatomical Correlations and Review. The British Journal of Psychiatry, 146, 184-197. http://dx.doi.org/10.1192/bjp.146.2.184

[13] Cummings, J.L., Miller, B., Hill, M.A. and Neshkes, R. (1987) Neuropsychiatric Aspects of Multi-Infarct Dementia and Dementia of the Alzheimer's Type. Archives of Neurology, 44, 389-393. http://dx.doi.org/10.1001/archneur.1987.00520160031010

[14] Khachaturian, Z.S. (1987) Status of Alzheimer's Disease Research. In: Altman, H.J., Ed., Alzheimer's Disease Problems, Prospects and Perspectives, Springer, New York, 183-189.

[15] Ranold, C.H. and Larry, B.H. (1994) Urinary and Fecal Incontinence. In: Handy, R.C., Turnbull, J.M., Clark, W. and Lancaster, M.N., Eds., Alzheimer's Disease. A Hand Book for Care Givers, 2nd Edition, Mosby-Year, Book, Inc., St. Louis, 199-212.

[16] Amaducci, L., Falcini, M. and Lippi, A. (1993) Descriptive Epidemiology for Risk Factors and Alzheimer's Disease. In: Corain, B., Iqbal, K., Nicolini, B., Winblad, H., Wisniewski and Zatta, P., Eds., Alzheimer's: Advances in Clinical and Basis Research, John Wiley \& Sons, Ltd., Hoboken, 105-111.

[17] Hasegawa, K. (1997) Aspects of Community Mental Health Care of the Elderly in Japan. International Journal of Mental Health, 8, 36-49.

[18] Nielsen, J. (1963) Geronotopsychiatric Period Presence Investigation in a Geographically Delimited Population. Acta Psychiatrica Scandinavica, 38, 307-330. http://dx.doi.org/10.1111/j.1600-0447.1962.tb01802.x

[19] Jorm, A.F., Korten, A.E. and Henderson, A.S. (1987) The Prevalence of Dementia: A Quantative Investigation of the Literature. Acta Psychiatrica Scandinavica, 76, 465-479. http://dx.doi.org/10.1111/j.1600-0447.1987.tb02906.x

[20] Ronald, C.H. and Lorry, B.H. (1994) Factors That Aggravate the Symptoms. In: Handy, R.C., Turnbull, J.M., Clark, W. and Lancaster, M.N., Eds., Alzheimer's Disease. A Hand Book for Care Givers, 2nd Edition, Mosby-Year, Book, Inc., St. Louis, 104-116.

[21] Ronald, C.H. (1994) Clinical Presentation. In: Handy, R.C., Turnbull, J.M., Clark, W. and Lancaster, M.N., Eds., Alzheimer's Disease. A Hand Book for Care Givers, 2nd Edition, Mosby-Year, Book, Inc., St. Louis, 74-85.

[22] Gauthier, S., Thal, L.J. and Rossor, M. (2001) The Future Diagnosis and Treatment of Alzheimer’s Disease. In: Gauthier, S., Ed., Clinical Diagnosis and Management of Alzheimer's Disease, Martin Dunitz, London, 369-398.

[23] Wells, C.E. (1983) Differential Diagnosis of Alzheimer's Dementia: Affective Disorder. In: Reisberg, B., Ed., Clinical Diagnosis and Different Diagnosis of Alzheimer's Disease, Free Press, New York, 193-197.

[24] Hachinsiki, V.C. (1983) Differential Diagnosis of Alzheimer’s Dementia: Multi Infarct Dementia. In: Reisberg, B., Ed., Alzheimer's Disease, Free Press, MacMilllan, New York, 188-192.

[25] Cummings, J. and Khachaturian, Z.S. (1996) Definitions and Diagnostic Criteria. In: Gauthier, S., Ed., Clinical Diagnosis and Management of Alzheimer's Disease, Dunitz, London, 3-31.

[26] Handerson, V.W. (1997) Estrogen, Cognition, and a Women’s Risk of Alzheimer's Disease. American Journal of Medicine, 103, 115-185.

[27] Rochon, P.A. and Gurwitz, H. (1996) Geriatrics: The Age of Women. The Lancet, 348, S118.

[28] Howard, L.F. and Reid, B. (2002) Neurological Disorders of Increased Prevalence in Women Migraine, Multiple Sclerosis and Alzheimer's Disease. In: Susan, G.K. and Clayton, A.H., Eds., A Comprehensive Text Book, The Guliford Press, New York, 467-480.

[29] Cotman, C.W., Bridges, R., Pike, C., Kesslak, D.L. and Copani, A. (1993) Mechanism of Neuronal Cell Death in Alzheimer's Disease. In: Corain, B., Iqbal, K., Nicolini, M., Winblad, B., Wisniewski, H. and Zatta, P., Eds., Alzheimer's 
Disease: Advances in Clinical and Basic Research, John Wiley \& Sons Ltd., Hoboken, 281-289.

[30] Greig, N.H., et al. (2004) New Therapeutic Strategies and Drug Candidates for Neurodegenrative Disease: P53 and TNF-Alpha Inhibitors, and GLP-1 Receptor Agonists. Annals of the New York Academy of Sciences, 1035, 290-315. http://dx.doi.org/10.1196/annals.1332.018

[31] Patterson, C., Feightner, J.W., Garcia, A.H., Sing, G.Y., Macknight, C. and Sadovnivk, A.D. (2008) Diagnosis and Treatment of Dementia: 1. Risk Assessment and Primary Prevention of Alzheimer's Disease. Canadian Medical Association Journal, 178, 548-556. http://dx.doi.org/10.1503/cmaj.070796

[32] Rosendorff, C., Beeri, M.S. and Silverman, J.M. (2007) Cordiovascular Risk Factors for Alzheimer's Disease. The American Journal of Geriatric Cardiology, 16, 143-149. http://dx.doi.org/10.1111/j.1076-7460.2007.06696.x

[33] Solfrizzi, V., et al. (2008) Life Style Related Factors in Predementia and Dementia Syndromes. Expert Review of Neurotherapeutics, 8, 133-158. http://dx.doi.org/10.1586/14737175.8.1.133

[34] Panza, F., Capurso, C., D’Introno A., Colacicco, A.M., Frisardi, V., Lorusso, M., Santamato, A., Seripa, D., Pilotto, A., Scafato, E., Vendemiate, G., Capurse, A. and Solfrizzi, V. (2009) Alcohol Drinking, Cognitive Functions in Older Age, Predementia and Dementia Syndromes. Journal of Alzheimer's Disease, 17, 7-31.

[35] Stern, Y.C. (2006) Cognitive Reserve and Alzheimer Disease. Alzheimer Disease and Associated Disorders, 20, S69S74.

[36] Shcherbatykh, I. and Carpenter, D.O. (2007) The Role of Metals in the Etiology of Alzheimer's Disease. Journal of Alzheimer's Disease, 11, 191-205.

[37] Rondeau, V., Commenges, D., Jaeqmin-Gadd, H. and Dartigues, J.-F. (2000) Relation between Aluminum Concentrations in Drinking Water and Alzheimer's Disease: An 8-Year Follow-Up Study. American Journal of Epidemiology, 152, 59-66. http://dx.doi.org/10.1093/aje/152.1.59

[38] Cataldo, J.K., Prochaska, J.J. and Glantz, S.A. (2010) Cigarette Smoking Is a Risk Factor for Alzheimer's Disease: An Analysis Controlling for Tobacco Industry Affiliation. Journal of Alzheimer's Disease, 19, 465-80.

[39] Khachaturian, Z.S. and Radebaugh, T.S. (1996) Alzheimer’s Disease: Cause(s), Diagnostic Treatment, and Care. In: Boca. Ratan, F. L. and Kim, H., CRC Press, 239-247.

[40] Geldmacher, D.S. (2007) Treatment Guidelines for Alzheimer's Disease: Redefining Perception in Primary Care. Primary Care Companion to the Journal of Clinical Psychiatry, 9, 113-121.

[41] Schmitt, F.A. and Wichems, C.H. (2006) A Systematic Review of Assessment and Treatment of Moderate to Severe Alzheimer's Disease. Primary Care Companion to the Journal of Clinical Psychiatry, 8, 158-169. http://dx.doi.org/10.4088/PCC.v08n0306

[42] Personalhealthfacts.com (1985) The Importance of Trace Minerals. NFM’s Nutrition Science News, 1-4.

[43] Romeyn, M. (1998) Vitamins, Minerals and Trace Elements. Nutrition and HIV, Jossey-Bass Inc., San Francisco.

[44] Herring, W.B., Leavell, B.S., Paixao, L.M. and Yoe, J.H. (1960) Trace Metals in Human Plasma and Red Blood Cells. American Journal of Clinical Nutrition, 8, 846-854.

[45] Khurshid, S.J. and Qureshi, I.H. (1984) The role of Inorganic Elements in Human Body. The Nucleus, 21, 3-23.

[46] Suhaila, R., Nasir, K., Shujaat, A., Nasim, U. and Mohammad, Z.I. (2004) Essential Trace Metals in Human Whole Blood in Relation to Environment. Pakistan Journal of Medical Research, 43, 1-5.

[47] Kumar, S. (1989) Medico-Physical Studies on Epilepsy and Other Neurological Disorders. Ph.D. Thesis, University of Delhi, Delhi.

[48] Mary, R.L.A., Kelvin, A.C., Sheila, D. and William, H.R. (2000) Nutrient Risk Assessment Implication for Food Fortification Policy, In: Rousel, A.M., Anderson, R.A. and Favrier, A., Eds., Trace Elements in Man and Animals, Kluwer Academic Publications, New York, Boston, Dordrecht, Lands, Moscow, 215-220.

[49] Alexander, G.S. (1995) Minerals and Human Health: The Rationale for Optimal and Balanced Trace Element Levels. Life Sciences Press, Tacoma, 1-5.

[50] Pike, R.L. and Brown, M.L. (1984) An Integrated Approach. Nutrition, John Wiley \& Sons, Hoboken, 197.

[51] Zumkley, H. (1987) Trace Elements in Medicine. Fresenius’ Zeitschrift für analytische Chemie, 327, 6. http://dx.doi.org/10.1007/BF00474512

[52] Davies, I.J.J. (1972) Clinical Significance of the Essential Biological Metals. Animal Health and Hygiene (General), William Heineman, London, 48-26.

[53] Burns, R.R. and Fell, G.S. (1976) Estimation and Interpretation of Plasma Zinc Fractions. Scottish Medical Journal, 21, 153-154.

[54] Prasad, A.S., and Oberleas, D. (1970) Binding of Zinc to Amino Acids and Serum Proteins in Vitro. Journal of Laboratory and Clinical Medicine, 76, 416-425. 
[55] Kelin, D. and Mann, J. (1940) Carbonic Anhydrase: Purification and Nature of the Enzyme. Biochemical Journal, 34, 1163-1176.

[56] Riordan, J.F. and Vallee, B.L. (1976) Structure and Function of Zinc Metalloenzymes. In: Prasad, A.S., Ed., Trace Elements in Human Health and Disease, Vol. 1, Academic Press, New York, 227-251.

[57] Chavapil, M., Zukowski, C.F., Hattler, B.G., Stankova, L., Montgomery, D., Carlson, E.C. and Ludwig, J.C. (1976) Zinc and Activity of Cell Membrane. In: Prasad, A.S., Ed., Trace-Elements in Human Health and Disease, Vol. 1, Academic Press, New York, 269-281.

[58] Prasad, A.S., Schulert, A.R., Sandstead, H.H., Miale Jr., A. and Farid, Z. (1963) Zinc, Iron and Nitrogen Content of Sweat in Normal and Deficient Subjects. Journal of Laboratory and Clinical Medicine, 62, 84-89.

[59] Walravens, P.A., Doornick, W.J.V. and Hambidge, K.M. (1978) Metals and Mental Function. The Journal of Pediatrics, 93, 535.

[60] Henkin, R.I., Patten, B.M., Re, P.K. and Bronzett, D.A. (1975) A Syndrome of Acute Zinc Loss. Archives of Neurology, 32, 745-751. http://dx.doi.org/10.1001/archneur.1975.00490530067006

[61] Dresti, I.E. (1984) Zinc in the Central Nervous System: The Emerging Interactions. In: Frederickson, C.J., Howell, G.A. and Kasarskis, E.J., Eds., The Neurobiology of Zinc Part A, Alan R.L., New York, 1-26.

[62] Fairbanks, V.F., Fahey, J.L. and Beutler, E. (1971) Clinical Disorders of Iron Metabolism. 2nd Edition, Grune and Stratton, New York, 1-486.

[63] Mc Cance and Widdowson, E.M. (1937) Absorption and Excretion of Iron. The Lancet, 2, 680-684.

[64] Gramick, S. (1946) Ferritin IX. Increase of the Protein Apoferritin in the Gastrointestinal Mucosa as a Direct Response to Iron Feeding. The Function of Ferritin in the Regulation of Iron Absorption. The Journal of Biological Chemistry, 164, 737-746.

[65] Moore, C.V., Doan, C.A. and Arrowsmith, W.R. (1937) Studies in Iron Transportation and Metabolism, Mechanism of Iron Transportations: Its Significance in Iron Utilization in Anemic States of Varied Etiology. Journal of Clinical Investigation, 16, 627-648. http://dx.doi.org/10.1172/JCI100889

[66] Mahler, H.R. and Elowe, D.G. (1953) DPNH-Cytochrome Reductase, a Ferroflavo Protein. Journal of the American Chemical Society, 75, 5769-5770. http://dx.doi.org/10.1021/ja01118a536

[67] Richert, D.A. and Westerfeld, W.W. (1954) The Relationship of Iron to Xanthime Oxidase. The Journal of Biological Chemistry, 209, 179-189.

[68] Fisher, H. and Zeile, K. (1929) Synthesis of Hematoprophyrin, Protoporphyrin and Hemin. European Journal of Organic Chemistry, 468, 98-116.

[69] Ingram, D.J.E., Gibson, J.F. and Perutz, M.F. (1956) Orientation of the Four Heme Groups in Hemoglobin. Nature, 178, 906-908. http://dx.doi.org/10.1038/178906a0

[70] Holmberg, G.C. and Laurell, C.B. (1947) Investigations in Serum Copper I. Nature of Serum Copper and Its Relation to the Iron-Binding Protein in Human Serum. Acta Chemica Scandinavica, 1, 944-950. http://dx.doi.org/10.3891/acta.chem.scand.01-0944

[71] Schade, A.L., Reinhart, R.W. and Levy, H. (1949) Carbon Dioxide and Oxygen in Complex Formation with Iron and Siderophilin, the Iron-Binding Compound of Human Plasma. Archives of Biochemistry and Biophysics, 20, 170-172.

[72] Lipschitz, D.A., Cook, J.D. and Finch, C.A. (1974) A Clinical Evaluation of Serum Ferritin as an Index of Iron Stores. The New England Journal of Medicine, 290, 1213-1216. http://dx.doi.org/10.1056/NEJM197405302902201

[73] Simes, M.A., Addiego Jr., J.E. and Dallman, P.R. (1974) Ferritin in Serum: Diagnosis of Iron Deficiency and Iron Overload in Infants and Children. Blood, 43, 581-590.

[74] Aikawa, J.K. (1971) The Relationship of Magnesium to Diseases in Domestic Animals and in Human. Charles C. Thomas, Springfield, 1-145.

[75] Aikawa, J.K. (1976) Biochemistry and Physiology of Magnesium. In: Prasad, A.S., Ed., II. Trace Elements in Humans: Health and Diseases, Academic Press, New York, 47-78.

[76] Widdowson, E.M., McCance, R.A. and Spray, C.N. (1951) The Clinical Composition of the Human Body. Clinical Science, 10, 113-125.

[77] Waterlow, J.C. (1992) Endocrine Changes in Severe PEM. In: Waterlow, J.C., Ed., Protein-Energy Malnutrition, Edward Arnold, London, 112-125.

[78] Classen, H.G. (1984) Magnesium and Potassium Deprivation and Supplementation in Animals and Man: Aspects in View of Intestinal Absorption. Magnesium, 3, 257-264.

[79] Al-Ghamdi, S.M., Cameron, E.C. and Sutten, R.A. (1994) Magnesium Deficiency: Pathophysiologic and Clinical Overview. American Journal of Kidney Diseases, 24, 737-752. http://dx.doi.org/10.1016/S0272-6386(12)80667-6 
[80] Wester, P. (1987) Magnesium. The American Journal of Clinical Nutrition, 45, 1305-1312.

[81] Krasner, B. (1979) Cardiac Effects of Magnesium with Special Referenceto Anaesthesia: A Review. Canadian Anaesthetists' Society Journal, 26, 181-185. http://dx.doi.org/10.1007/BF03006978

[82] Furukawa, Y. and Chiba, S. (1981) Effects of Magnesium on the Isolated, Blood-Perfused Atrial and Ventricular Preparations of the Dog Heart. Japanese Heart Journal, 22, 239-246.

[83] Stark, G., Stark, U., Pilger, E., Honigl, K., Bertuch, H. and Tritthart, H.A. (1989) The Influence of Elevated $\mathrm{Mg}^{2+}$ Concentrations on Cardiac Electrophysiological Parameters. Cardiovascular Drugs and Therapy, 3, 183-189. http://dx.doi.org/10.1007/BF01883863

[84] Haigney, M.C.P., Berger, R., Schulman, S., Gerstenblith, G., Tunin, C., Silver, B., Silverman, H.S., Tomaselli, G. and Calkins, H. (1997) Tissue Magnesium Levels and the Arrhythmic Substrate in Humans. Journal of Cardiovascular Electrophysiology, 8, 980-986. http://dx.doi.org/10.1111/j.1540-8167.1997.tb00620.x

[85] Ireland, P. and Fordtran, J.S. (1973) Effect of Dietary Calcium and Age on Jejunal Calcium Absorption in Humans Studied by Intestinal Perfusion. Journal of Clinical Investigation, 52, 2672-2681. http://dx.doi.org/10.1172/JCI107461

[86] Heaney, R.P., Saville, P.D. and Recker, R.R. (1975) Calcium Absorption as a Function of Calcium Intake. The Journal of Laboratory and Clinical Medicine, 85, 881-890.

[87] Wilkinson, R. (1976) Phosphate and Magnesium Metabolism. In: Nordin, B.E.C., Ed., Clinical Physiology and Diagnostic Procedures, Churchill Livingstone, Edinberg, 36-112.

[88] Marshall, D.H. (1976) Calcium and Phosphate Kinetics Calcium, Phosphate and Magnesium Metabolism. In: Nordin, B.E.C., Ed., Clinical Physiology and Diagnostic Procedures, Churchill Livingstone, Edinberg, 257-297.

[89] Morris, H.A., Need, A.G., Horowitz, M., O’Loughlin, P.D. and Nordin, B.E. (1991) Calcium Absorption in Normal and Osteoporotic Postmenopausal Women. Calcified Tissue International, 49, 240-243. http://dx.doi.org/10.1007/BF02556211

[90] Ebeling, P.R., Yergey, A.L., Vieira, N.E., Burritt, M.F., O’Fallon, W.M., Kumar, R. and Riggs, B.L. (1994) Influence of Age on Effects of Endogeneous 1,25-Dihydroxyvitamin D on Calcium Absorption in Normal Women. Calcified Tissue International, 55, 330-334. http://dx.doi.org/10.1007/BF00299309

[91] Need, A.G., Morris, H.A., Horowitz, M., Scopacasa, E. and Nordin, B.E. (1998) Intestinal Calcium Absorption in Men with Spinal Osteoporosis. Clinical Endocrinology, 48, 163-168. http://dx.doi.org/10.1046/j.1365-2265.1998.3681181.x

[92] Nordin, B.E.C. (1976) Nutritional Considerations. In: Nordin, B.E.C., Ed., Clinical Physiology and Diagnostic Procedures, Edinberg, Churchill Livingstone, 1-35.

[93] Kent, G.N., Price, R.I., Gutteridge, D.H., Allen, J.R., Barnes, M.P., Hickling, C.J., Retallack, R.W., Wilson, S.G., Devlin, R.D., Price, R.I., Smith, M., Bhagat, C.I., Davies, C. and St. Johns, A. (1990) Human Lactation: Forearm Trabecular Bone Loss, Increased Bone Turnover, and Renal Conservation of Calcium and Inorganic Phosphate with Recovery of Bone Mass Following Weaning. Journal of Bone and Mineral Research, 5, 361-369. http://dx.doi.org/10.1002/jbmr.5650050409

[94] Lopez, J.M., Gonzalez, G., Reyes, V., Campino, C. and Diaz, S. (1996) Bone Turnover and Density in Healthy Women during Breastfeeding and after Weaning. Osteoporosis International, 6, 153-159. http://dx.doi.org/10.1007/BF01623940

[95] Chan, G.M., McMurray, M., Westover, K., Engelbert-Fenton, K. and Thomas, M.R. (1987) Effects of Increased Dietary Calcium Intake upon the Calcium and Bone Mineral Status of Lacting Adolescent and Adult Women. The American Journal of Clinical Nutrition, 46, 319-323.

[96] Katz, M. and Steihm, E.R. (1977) Host Defense in Malnutrition. Pediatrics, 59, 490-495.

[97] Suskind, R.M. (1977) Malnutritian and the Immune Response. Kroc Foundation Series, Vol. 7, Raven Press, New York, 468

[98] Bongiorni-Malave, I.B. and Pocino, M. (1980) Abnormal Regulatory Control of the Antibody Response to Hetrologous Erythrocytes in Protein-Calorie-Malnourished Mice. Clinical Immunology and Immunopathology, 16, 19-29. http://dx.doi.org/10.1016/0090-1229(80)90162-2

[99] Malave, I., Nemeth, A. and Pocino, M. (1980) Changes in Lymphocyte Populations in Proteins-Caloriedefieient Mice. Cellular, 49, 235-249.

[100] Gershwin, M.E., Keen, C.L., Fletcher, M.P. and Hurley, L.S. (1988) Trace Element Deficiencies and Immune Responsiveness. In: Hurley, L.S., Keen, C.L., Lonnerdal, B. and Rucker, R.B, Eds., Trace Elements in Man and Animals, Plenum Press, New York and London, 85-89.

[101] Rigas, D.A., Rigas, E.C. and Head, C. (1979) Biophasic Toxicity of Diethyldithiocarbamate, a Metal Chelator, to T Leymphocytes and Polymorphonucuclear Granulocytes: Reversal by Zinc and Copper. Biochemical and Biophysical 
Research Communications, 88, 373-379. http://dx.doi.org/10.1016/0006-291X(79)92058-8

[102] Underwood, E.J. (1977) Trace Element in Human and Mimal Nutrition. In: Mertz, W., Ed., 4th Edition, Academic Press, New York, 430-433.

[103] Daniel, P.P. (1988) Aluminum and Alzheimer's Disease; Methodologic Approaches. In: Sigel, H. and Sigel, A., Eds., Metal Ions in Biological Systems, Vol. 24, Marcel Dekker, Inc., New York, 259-283.

[104] Ehmann, W.D., Markesbery, W.R., Alauddin, M., Hassain, T.I. and Brubaker, E.H. (1986) Brain Trace Elements in Alzheimer's Disease. Neurotoxicology, 7, 197-206.

[105] Cornett, C.R., Markesbery, W.R. and Ehmann, W.D. (1998) Imbalances of Trace Elements Related to Oxidative Damage in Alzheimer's Disease Brain. Neurotoxicology, 19, 339-345.

[106] Huseyin, V., Hilmi, D., Yusuf, K., Ibrahim, E. and Namik, D. (2010) Alterations of Plasma Magnesium, Copper, Zinc, Iron, and Selemium Concentrations and Some Related Erythrocyte Antioxidant Enzyme Activities in Patients with Alzheimer's Disease. Journal of Trace Elements in Medicine and Biology, 24, 169-173. http://dx.doi.org/10.1016/j.jtemb.2010.02.002

[107] Ashley, I.B. and Tanzi, R.E. (1995) The Role of Zinc in the Cerebrad Deposition of A $\beta$ Amyloid in Alzheimer's Disease. In: Iqbal, K., Mortimen, J.A., Winblad, B. and Wisniewski, H.M., Eds., Research Advances in Alzheimer's Disease and Related Disorders, John Wiley \& Sons, Hoboken, 607-618.

[108] Wenstrup, D., Ehmann, W.D. and Markesbery, W.R. (1990) Trace Element Imbalance in Isolated Sub Cellular Fractions of Alzheimer's Disease Brains. Brain Research, 533, 125-131. http://dx.doi.org/10.1016/0006-8993(90)91804-P

[109] Cantantindis, J. (1990) Maladie d’Alzheimer et la théorie du Zinc. L’Encephale, 16, 231-9.

[110] Corrigan, F.M., Reynolds, G.P. and Ward, M.I. (1993) Hippocampal Tin, Aluminium and Zinc in Alzheimer’s Disease. Biometals, 6, 149-154. http://dx.doi.org/10.1007/BF00205853

[111] Hershey, C.O., Hershey, L.A., Varnes, A., Vibhakar, S.D. and Lavin, P. and Strain, W.H. (1983) Cerebrospinal Fluid Trace Element Content in Dementia: Clinical Radiologic and Pathologic Correlations. Neurology, 33, 1350-1353. http://dx.doi.org/10.1212/WNL.33.10.1350

[112] Lui, E., Fisman, M., Wang, C. and Diaz, F. (1990) Metals and the Liver in Alzheimer’s Disease: An Investigation of Hepatic Zinc, Copper, Cadmium and Metallothianein. Journal of the American Geriatrics Society, 38, 633-639.

[113] Backstrom, J.R., Miller, C.A. and Tökde’s, Z.A. (1992) Characterization of Neutral Proteinases from Alzheimer-Affected and Control Brain Specimens: Identification of Calcium-Dependent Metalloproteinase from the Hippocampus. Journal of Neurochemistry, 58, 983-992. http://dx.doi.org/10.1111/j.1471-4159.1992.tb09352.x

[114] Uchida, Y., Takio, K., Titani, K., Ihara, Y. and Tomonaga, M. (1991) The Growth Inhibitory Factor That Is Deficient in the Alzheimer's Disease Brain Is a 68-Amino Acid Metallothianein-Like Protein. Neuron, 7, 337-347. http://dx.doi.org/10.1016/0896-6273(91)90272-2

[115] Franceschi, C., Chiricolo, M., Licastro, F., Zannotti, M., Masi, M., Macchegiani, E. and Fabris, N. (1988) Oral Zinc Supplementation in Down's Syndrome: Restoration of Thymic Endocrine Activity and Some Immune Defects. Journal of Mental Deficiency Research, 32, 169-181.

[116] Bjorkstem, B., Back, O., Gustavason, K.H., Hallmans, G., Hagglof, B. and Tarnvik, A. (1980) Zinc and Immune Function in Down's Syndrome. Acta Paediatrica Scandinavica, 69, 183-187.

[117] Napolitano, G., Palka, G., Grimaldi, S., Giuliani, C., Laglia, G., Calabarese, G., Satta, M.A., Neri, G. and Monaco, F. (1990) Growth and Delay in Down Syndrome and Zinc Sulphate Supplementation. American Journal of Medical Genetics. Supplement, 7, 63-65.

[118] Mc Lachlan, C., Kruck, T.P., Lukiw, W.J. and Krishnan, S.S. (1991) Would Decreased Aluminium Ingestion Reduce the Incidence of Alzheimer's Disease? Canadian Medical Association Journal, 145, 793-804.

[119] Frederickson, C.J., Klitenick, M.A., Manten, W.I. and Kirkpatrick, J.B. (1983) Cytoarchitectonic Distribution of Zinc in the Hippocampus of Man and the Rat. Brain Research, 272, 335-339. http://dx.doi.org/10.1016/0006-8993(83)90858-2

[120] Frederickson, C.J. (1989) Neurobiology of Zinc and Zinc Containing Neurons. International Review of Neurobiology, 31, 145-328. http://dx.doi.org/10.1016/S0074-7742(08)60279-2

[121] Choi, D.W., Yokoyama, M. and Koh, J. (1988) Zinc Neurotoxicity in Cortical Cell Culture. Neuroscience, 24, 67-79. http://dx.doi.org/10.1016/0306-4522(88)90312-0

[122] Stewart, G.R., Frederickson, C.J., Howell, G.A. and Gage, F.H. (1984) Choleinergicdeneutruation Induced Increase of Chelatable Zinc in Mossy-Fiber Region of the Hippocampal Formation. Brain Research, 290, 43-51. http://dx.doi.org/10.1016/0006-8993(84)90734-0

[123] Hyman, B.T., Van Hoesen, G.W, Kroner, L.J. and Damasio, A.R. (1986) Perforant Pathway Changes and the Memory Impairment of Alzheimer's Disease. Annals of Neurology, 20, 472-481. http://dx.doi.org/10.1002/ana.410200406 
[124] Hicks, N.M., Brammer, M.J., Hymans, N. and Levy, R. (1987) Platelet Membrane Properties in Alzheimer’s and Multi-Infarct Dementias. Alzheimer Disease and Associated Disorders, 1, 90-97. http://dx.doi.org/10.1097/00002093-198701020-00004

[125] Pohit, J., Saha, K.C. and Pal, B. (1981) A Zinc Tolerance Test. Clinica Chimica Acta, 114, 279-281. http://dx.doi.org/10.1016/0009-8981(81)90402-2

[126] Sandström, B., Arvidsson, B., Cederblad, A. and Björn-Rasmussen, E. (1980) Zinc Absorption from Composite Metals I. The Significance of Wheat Extraction Rate, Zinc, Calcium, and Protein Content in Metals Based on Bread. American Journal of Clinical Nutrition, 33, 739-745.

[127] Burnet, F.M. (1981) A Possible Role of Zinc in Dementia. The Lancet, 1, 186-188. http://dx.doi.org/10.1016/S0140-6736(81)90062-3

[128] Markesbery, W.R., Ehmann, W.D., Hossain, T.I.M., Alauddin, M. and Goodin, D.T. (1981) Instrumental Neutron Activation Analysis of Brain Aluminium in Alzheimer's Disease and Aging. Annals of Neurology, 10, 511-516. http://dx.doi.org/10.1002/ana.410100604

[129] Ehmann, W.D., Markesbery, W.R., Alauddin, M., Hossain, T.I.M. and Brubaker, E.H. (1986) Brain Trace Elements in Alzheimer's Disease. Neurotoxicology, 7, 197-206.

[130] Ehmann, W.D., Markesbery, W.R. and Alauddin, M. (1984) Quantitation, Localization and Variations of Brain Zinc with Aging by Instrumental Neuton Activation Analysis. In: Frederickson, C.J., Howell, G.A. and Kassarskis, E.J., Eds., Neurobiology of Zinc. Part A. Physiochemistry, Anatomy, and Techniques, Alan R. Liss, New York, 329-342.

[131] Thompson, C.M., Markesbery, W.R., Ehmann, W.D. and Vance, D.E. (1988) Regional Brain Trace Elements Studies in Alzheimer's Disease. Neurotoxicology, 9, 1-8.

[132] Hershey, L.A., Hershey, C.O., Varnes, A.W., Wongmongkolrit, T. and Strain, W.H. (1984) Zinc Content in CSF, Brain and Other Tissues in Alzheimer's Disease and Aging. In: Frederickson, C.J., Howell, G.A. and Kassarskis, E.J., Eds., The Neurobiology of Zinc. Part B. Deficiency, Toxicity and Pathology, Alan R. Liss, New York, 325-334.

[133] Markesbery, W.R. and Ehmann, W.D. (1994) Brain Trace Elements in Alzheimer’s Disease. In: Terry, R.D., Katzman, R. and Bick, K.L., Eds., Alzheimer's Disease, Raven Press Ltd., New York, 353-367.

[134] Goodman, L. (1953) Alzheimer's Disease: A Clinico-Pathologic Analysis of Twenty Three Cases with a Theory on Pathogenesis. The Journal of Nervous and Mental Disease, 117, 97-130. http://dx.doi.org/10.1097/00005053-195308000-00001

[135] Good, P.F., Perl, D.P., Bierer, L.M. and Schmeidler, J. (1992) Selective Accumulation of Aluminum and Iron in the Neurofibrillary Tangles of Alzheimer's Disease: A Laser Microprobe (LAMMA) Study. Annals of Neurology, 31, 286292. http://dx.doi.org/10.1002/ana.410310310

[136] Andorn, M.C., Britten, R.S. and Bacon, B.R. (1990) Evidence That Lipid Peroxidation and Total Iron Are Increased in Alzheimer's Brain. Neurobiology of Aging, 11, 316-323. http://dx.doi.org/10.1016/0197-4580(90)90814-G

[137] Connor, J.R., Menzies, S.L., St. Martin, S.M., Mufison, E.J. (1992) A Histochemical Study of Iron, Transferrin and Ferritin in Alzheimer's Diseased Brains. Journal of Neuroscience Research, 31, 75-83. http://dx.doi.org/10.1002/jnr.490310111

[138] Ehmann, W.D., Markesbery, W.R. Alauddin, M.T.I.M. and Brubaker, E.H. (1986) Brain Trace Elements in Alzheimer's Disease. Neurotoxicology, 7, 197-206.

[139] Fleming, J. and Joshi, J.G. (1987) Ferritin: Isolation of Aluminum-Ferritin Complex from Brain. Proceedings of the National Academy of Sciences of the United States of America, 84, 7866-7870. http://dx.doi.org/10.1073/pnas.84.22.7866

[140] Switzer, R.C., Martin, T.L., Campbell, S.K., Parker, J.C. and Caldwell, E.D. (1986) Iron and Ferritin in the Neuritic Plaques of Alzheimer's Disease. Society for Neuroscience Abstracts, 100.

[141] Grundke-Iqbal, I., Fleming, J., Tung, Y.C., Lassmann, H., Iqbal, K. and Joshi, J.G. (1990) Ferritin Is a Component of the Neuritic (Seniles) Plaque in Alzheimer Dementia. Acta Neuropathologica, 81, 105-110. http://dx.doi.org/10.1007/BF00334497

[142] Connor, J.R. Menzies, S.L., St. Martin, S.M. and Mufsan, E.J. (1990) Cellular Distribution of Transferrin, Ferritin, and Iron in Normal and Aged Human Brains. Journal of the Neurological Sciences, 27, 595-611.

[143] Sherrington, R., Rogaeu, E.I., Liang, Y., Rogaeva, E.A., Levesque, G., Ikeda, M., Chi, H., Lin, C., Li, G., Holman, K., Tsuda, T., Mar, L., Fencin, T.F., Bruni, A.C., Montesi, M.P., Sorbi, S., Rainero., I., Phinessi, L., Nee, L., Chumako, I., Pollen, D., Brookes, A., Sanseau, P., Polinsky, R.J., Wasco, W., Dasilva, H.A.R., Haines, J.L., Pericak-Vance, M.A., Tanzi, R.E., Roses, A.D., Fraser, P.E., Rommes, T.M. and St. George-Hyslof, P.H. (1995) Cloning of a Gene Bearing Missense Mutations in Early-Onset Familial Alzheimer's Disease. Nature, 375, 754-760. http://dx.doi.org/10.1038/375754a0 
[144] Peterson, C., Gibson, G.E. and Blass, J.P. (1985) Altered Calcium Uptake in Cultured Skin Fibroblasts from Patients of Alzheimer's Disease. The New England Journal of Medicine, 312, 1063-1064.

http://dx.doi.org/10.1056/NEJM198504183121618

[145] Ito, E., Oka, K., Etcheberrigaray, R., Nelson, T.T., Mcphie, D.L., Totel-Grehl, B., Gibson, G.E. and Alkan, D.L. (1994) Internal $\mathrm{Ca}^{2+}$ Mobilization Is Altered in Fibroblasts from Patients with Alzheimer's Disease. Proceedings of the National Academy of Sciences of the United States of America, 91, 534-538. http://dx.doi.org/10.1073/pnas.91.2.534

[146] Peterson, C., Ratan, R. R., Shelanski, M. L. and Goldman, J. E. (1986) Cytosolic Free Calcium and Cell Spreading Decrease in Fibroblasts from Aged and Alzheimer's Donors. Proceedings of the National Academy of Sciences of the United States of America, 83, 7999-8001. http://dx.doi.org/10.1073/pnas.83.20.7999

[147] Peterson, C. and Goldman, T.E. (1988) Alteration in Calcium Content and Biochemical Processes in Cultured Skin Fibroblasts from Aged and Alzheimer's Donors. Proceedings of the National Academy of Sciences of the United States of America, 83, 2758-2762. http://dx.doi.org/10.1073/pnas.83.8.2758

[148] Chakroborty, S. and Slutzmann, G.E. (2011) Early Calcium Dysregulation in Alzheimer's Disease: Setting the Stage for Synaptic Dysfunction. Science China. Life Science, 54, 752-762.

[149] Mc Coy, K.R., Mullins, R.D., New Comb, T.G., Pavlinkova, R.J., Nee, L.E. and Sisken, J.E. (1991) Serum and Bradykinin-Induced Calcium Transients in Familial Alzheimer’s Fibroblasts. Neurobiology of Aging, 14, 447-455. http://dx.doi.org/10.1016/0197-4580(93)90103-I

[150] Huang, H.M., Toral-Barza, L., Thaler, H., Totel-Grehl, B. and Gibson, G.E. (1991) Inositol Phosphates and Interacellular Calcium after Bradykinin Simulation in Fibroblasts from Young, Normal Aged and Alzheimer's Donors. Neurobiology of Aging, 12, 469-473. http://dx.doi.org/10.1016/0197-4580(91)90075-U

[151] Borden, L.A., Maxfield, F.R., Goldman, J.E. and Shelanski, M.L. (1992) Resting $\left[\mathrm{Ca}^{2+}\right]_{\mathrm{i}}$ and $\left[\mathrm{Ca}^{2+}\right]_{\mathrm{i}}$ Transient Are Similar in Fibrablasts from Normal and Alzheimer's Disease Donors. Neurobiology of Aging, 13, 33-38. http://dx.doi.org/10.1016/0197-4580(92)90005-I

[152] Khachaturian, Z.S. (1984) Towards Theory of Brain Aging. In: Kay, D.S. and Burrows, G.W., Eds., Handbook of Studies on Psychiatry and Old Age, Elsevier, Amsterdam, 7-30.

[153] Mattson, M.P. (1992) Calcium as Sculptor and Destroyer’s of Neural Circuity. Experimental Gerontology, 27, 29-49. http://dx.doi.org/10.1016/0531-5565(92)90027-W

[154] Canzoniero, L.M. and Snider, B.J. (2005) Calcium in Alzheimer's Disease Pathogenesis: Too Much, Too Little or in the Wrong Place. Journal of Alzheimer's Disease, 8, 147-154.

[155] Martyn, C.M., Singh, S. and Wood, P.J. (1989) Calcium Metabolism in Alzheimer's Disease. A Case-Control Study, Gerontology, 35, 153-157.

[156] Mattson, M.P. and Chan, S.L. (2003) Neuronal and Glial Calcium Signalling in Alzheimer’s Disease. Cell Calcium, 34, 385-397. http://dx.doi.org/10.1016/S0143-4160(03)00128-3

[157] Woods, N.K. and Padmanabhan, J. (2012) Neuronal Calcium Signalling and Alzheimer's Disease. Advances in Experimental Medicine and Biology, 740, 1193-1217. http://dx.doi.org/10.1007/978-94-007-2888-2_54

[158] Pascale, A. and Etcheberrigaray, R. (1997) Calcium Alterations in Alzheimer’s Disease: Pathophysiology, Models and Therapeutic Opportunities. Pharmacological Research, 39, 81-88. http://dx.doi.org/10.1006/phrs.1998.0411

[159] Frank, M.L. (2002) Calcium Dyshomeastasis and Intracellular Signalling in Alzheimer's Disease. Nature Reviews Neuroscience, 3, 862-872. http://dx.doi.org/10.1038/nrn960

[160] Bojarski, L., Herms, J. and Kuznicki, J. (2008) Calcium Dyes Regulation in Alzheimer's Disease. Neurochemistry International, 52, 621-633. http://dx.doi.org/10.1016/i.neuint.2007.10.002

[161] Berridge, M.J. (2010) Calcium Hypothesis of Alzheimer’s Disease. Pflügers Archiv: European Journal of Physiology, 459, 441-449. http://dx.doi.org/10.1007/s00424-009-0736-1

[162] Cilliler, A.E., Ozturk, S. and Ozbakir, S. (2007) Serum Magnesium Level And clinical Deterioration in Alzheimer's Disease. Gerontology, 53, 419-422. http://dx.doi.org/10.1159/000110873

[163] Ali, S.S., Mahdi, F., Jatar, M., Mohammad, M. and Robas, M. (2013) Study on Serum Magnesium Level in Alzheimer's Disease and Its Relationship with the Stage of Disease. Medical Journal of Tabriz University of Medical Science, 32, 57-621.

[164] Durlach, J. (1990) Magnesium Depletion and Pathogenesis of Alzheimer’s Disease. Magnesium Research, 3, $217-218$.

[165] Glick, J.L. (1990) Dementias: The Role of Magnesium Deficiency and an Hypothesis Concerning the Pathogenesis of Alzheimer's Disease. Medical Hypotheses, 31, 211-225. http://dx.doi.org/10.1016/0306-9877(90)90095-V

[166] Korf, J., Gramsbergn, J.B.P., Prenen, G.H.M. and Go, K.G. (1986) Cation Shifts and Excitotoxins in Alzheimer and Huntington Disease and Experimental Brain Damage. Progress in Brain Research, 70, 213-226. http://dx.doi.org/10.1016/S0079-6123(08)64306-X 
[167] Barbagallo, M., Beluedere, M., Di Bella, G. and Domingues, L.J. (2011) Dementia Less Likely with Increased Levels of Magnesium etc. Magnesium Research, 24, S115-S121.

[168] Mielke, M.M., Zandi, P.P., Blennow, K., Gustafson, D., Sjögren, M. Rosengren, L. and Skoog, I. (2006) Low Serum Potassium in Mid Life Associated with Decreased Cerebrospinal Fluid A $\beta 42$ in Late Life. Alzheimer Disease and Associated Disorders, 20, 30-36. http://dx.doi.org/10.1097/01.wad.0000201848.67954.7d

[169] Diebel, M.A., Ehmann, W.D. and Markesbery, W.R. (1996) Copper, Iron and Zinc Imbalances in Severely Degenerated Brain Regions in Alzheimer's Disease: Possible Relation to Oxidative Stress. Journal of the Neurological Sciences, 143, 137-142. http://dx.doi.org/10.1016/S0022-510X(96)00203-1

[170] Huseyin, V., Hilmi, D., Yusuf, K., Ibrahim, E. and Nam, K.D. (2010) Alterations of Plasma Magnesium, Copper, Zinc, Iron and Selenium Concentrations and Some Related Erythrocyte Antioxidant Enzyme Activities in Patients with Alzheimer's Disease. Journal of Trace Elements in Medicine and Biology, 24, 169-173. http://dx.doi.org/10.1016/j.jtemb.2010.02.002

[171] Philip, G.S. (1992) Theory of the Aetiology of Alzheimer’s Disease. Brain Biochemistry and Brain Disorders, Oxford University Press, Oxford, New York, 342.

[172] Mattiello, G., Gerotto, M., Favarato, M., Lazzari, F., Gasparoni, G., Goniratu, L., Mazzolini, G., Scarpa, G., Zanoboni, V., Pilone, M.G. and Zafta, P.F. (1993) Plasma Micro Elemental Analysis from Alzheimer's and Multi Infarctual Dementia Patients. In: Corain, B., Iqbal, K., Nicolini, M., Winblad, B., Wisneiwski, H. and Zatta, P., Eds., Alzheimer's Disease: Advances in Clinical and Basic Research, John Wiley \& Sons, Hoboken, 267-272.

[173] Mc Lachlan, D.R. (1986) Aluminium and Alzheimer’s Disease. Neurobiology of Aging, 1, 525-532. http://dx.doi.org/10.1016/0197-4580(86)90102-8

[174] Cornett, C.R., Ehmann, W.D. and Wekstein, D.R. and Markesbery, W.R. (1998) Trace Elements in Alzheimer's Disease Pituatry Glands. Biological Trace Element Research, 62, 107-114. http://dx.doi.org/10.1007/BF02820026

[175] Walsh, A. (1956) The Application of Atomic Absorption Spectra to Chemical Analysis. Spectrochimica Acta, 7, 108117. http://dx.doi.org/10.1016/0371-1951(55)80013-6

[176] Skoog, D.A., Holler, F.J. and Nieman, T.A. (1998) Prinicples of Instrumental Analysis. 5th Edition, Harcourt Brace \& Company, Philadelphia, 849.

[177] John, H., Maxwell, J.D., Stewart, D.A., Parsons, V. and Williams, R. (1971) Altered Calcium Metabolism in Epileptic Children on Anti-Convulsants. British Medical Journal, 4, 202-204. http://dx.doi.org/10.1136/bmj.4.5781.202

[178] Prasad, R., Singh, A., Das, B.K., Upadhyay, R.S., Singh, T.B. and Mishra, O.P. (2009) Cerebrospinal Fluid and Serum Zinc Copper, Magnesium and Calcium Levels in Children with Idiopathic Seizure. Journal of Clinical and Diagnostic Research, 3, 1841-1846.

[179] Lech, T. (2001) Calcium and Magnesium Content in Hair as a Predictor of Disease in Children. Trace Elements and Electrolytes, 18, 112-121.

[180] Avci, H., Kizilkan, N. and Yaman, M., (2008) Comparison of Trace Elements Concentrations in Scalp Hair of Epileptic and Normal Subjects. Trace Elements and Electrolytes, 25, 147-155. http://dx.doi.org/10.5414/TEP25147

[181] Barlow, P.J., Francois, P.E., Goldberg, I.J. Richardson, I., Izmeth, M.G., Kumpeson, K. and Sykes, P. (1986) Trace Metal Abnormalities in Long Stay Hyperactive Mentally Handicapped Children and Agitates Senile Dements. Journal of the Royal Society of Medicine, 79, 581-583.

[182] Khanna, R.S., Kumar, R., Asthana, R.K., Negi, R., Pande, D., Kumar, A. and Khanna, H.D. (2009) Role of Trace Element and Antioxidants in Free Radical Mediated Injury in Neonates. MASAUM Journal of Basic and Applied Science, 1, 543-547.

[183] Adnan, M., Ahmed, G., Khaled, O., Indress, A.M., Ahmed, A., Hiatham, T. and Wall, H. (2010) Simultaneous Determination of Cd, Pd, Cu Zn and Se in Human Blood of Jordanian Smokers by ICP-OES. Biological Trace Element Research, 133, 1-11. http://dx.doi.org/10.1007/s12011-009-8405-y

[184] Guidotti, T.L., McNamra, J. and Moses, M.S. (2008) The Interpretation of Trace Element Analysis in Body Fluids. Indian Journal of Medical Research, 128, 524-532.

[185] Deniz, T., Ali, H.T. and Saraymen, R (2008) The Effects of Antiepileptic Drugs on Serum and Hair Trace Element Levels. Ankara Üniversitesi Tıp Fakültesi Mecmuası, 61, 73-76.

[186] Soylak, M., Saracoglu, S., Divrikli, U. and Elci, L. (2001) Copper and Zinc Concentrations of Serum Samples of Healthy People Living in Tokat, Turkey. Trace Element and Electrolytes, 18, 47-40.

[187] Delves, H.T., Clayton, B.E. and Bicknel, J. (1973) Concentration of Trace Metals in the Blood of Children. British Journal of Preventive Social Medicine, 27, 100-107.

[188] Kumar, S., Bajaj, M., Jain, D.C. and Yadav, H.S. (1988) A Search for the Trace Elemental Deficiencies in Grand Mal Epilepsy Using Atomic Absorption Spectrophotometric Technique and Catalytic Agent in the Cellular Enzyme Reac- 
tion. Proceedings of the World Congress on Clinical Nutrition, 1, 115A-121A.

[189] Smith, W.G. and Bone, I. (1982) Copper, Zinc and Magnesium Plasma Levels in Epilepsy. Journal of Neurology, Neurosurgery Psychiatry, 45, 1072-1073. http://dx.doi.org/10.1136/jnnp.45.11.1072

[190] Kaji, M., Ito, N., Okuno, T., Momoi, T., Sasaki, H., Yamanake, C., Yorifuji, T. and Mikawa, H. (1992) Serum Copper and Zinc Levels in Epileptic Children with Valporate Treatment. Epilepsia, 33, 555-557. http://dx.doi.org/10.1111/j.1528-1157.1992.tb01709.x

[191] Kumar, S., Kumar, V. and Jain, D.C. and Mittal, R. (2013) Trace Element Analysis in Epileptic Children. Open Journal of Applied Sciences, 3, 449-476. 